Prepared in cooperation with the Wisconsin Department of Natural Resources

\title{
Effects of Best-Management Practices in Bower Creek in the East River Priority Watershed, Wisconsin, 1991-2009
}

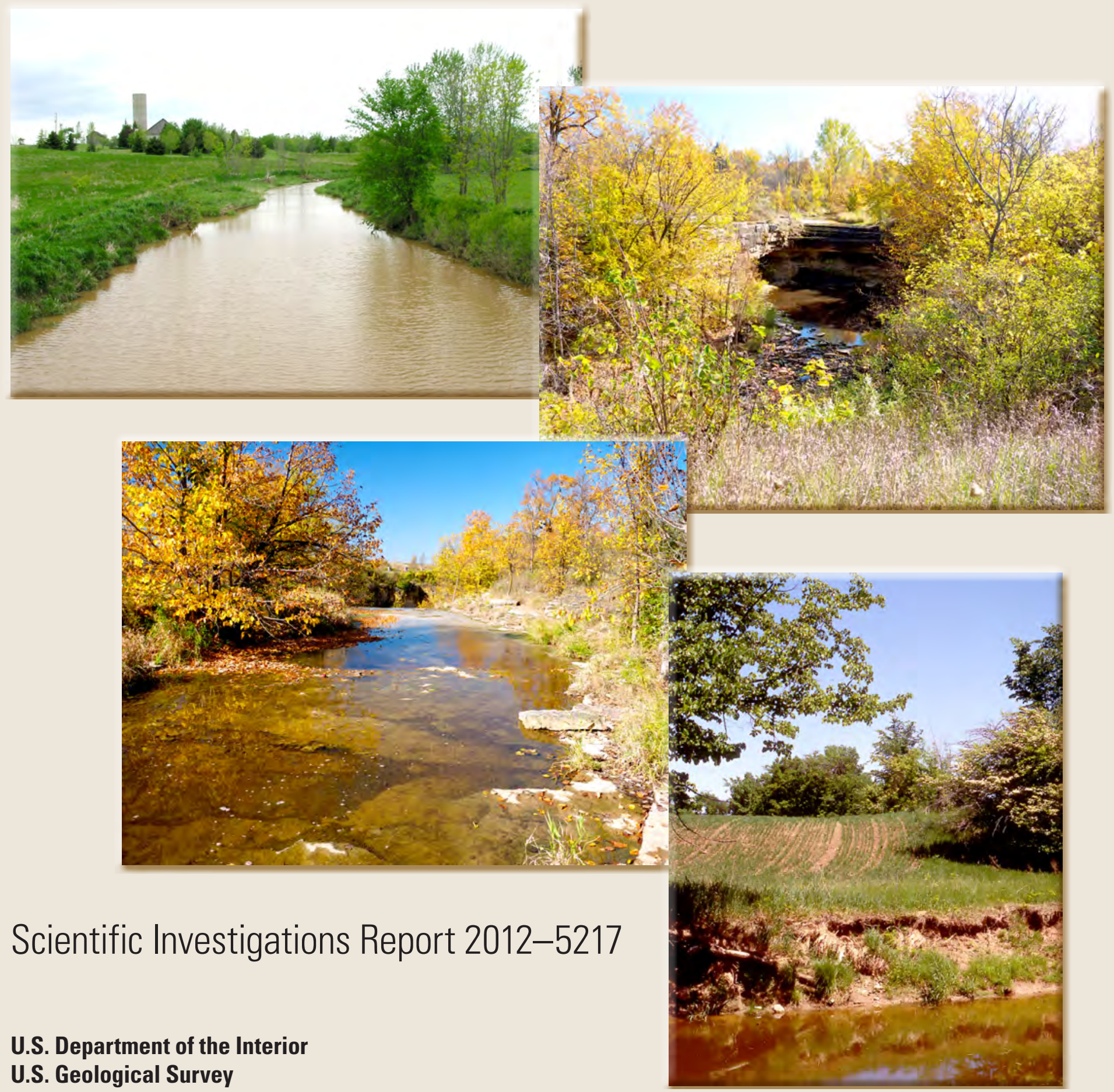




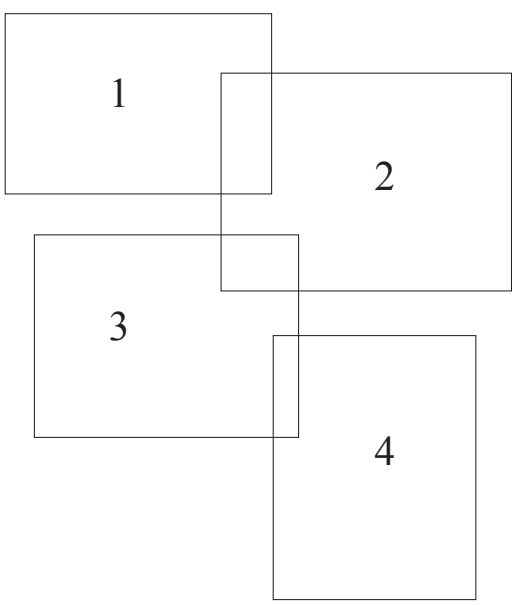

Cover. Areas within the Bower Creek Watershed near De Pere, Wisconsin. Photographs 1 and 4 courtesy of Judy A. Horwatich (U.S. Geological Survey). Photographs 2 and 3 courtesy of Daniel L. Olson (U.S. Geological Survey). 


\section{Effects of Best-Management Practices in Bower Creek in the East River Priority Watershed, Wisconsin, 1991-2009}

By Steven R. Corsi, Judy A. Horwatich, Troy D. Rutter, and

Roger T. Bannerman

Prepared in cooperation with the Wisconsin Department of Natural Resources

Scientific Investigations Report 2012-5217 


\section{U.S. Department of the Interior \\ KEN SALAZAR, Secretary \\ U.S. Geological Survey \\ Marcia K. McNutt, Director}

U.S. Geological Survey, Reston, Virginia: 2013

For more information on the USGS - the Federal source for science about the Earth, its natural and living resources, natural hazards, and the environment, visit http://www.usgs.gov or call 1-888-ASK-USGS.

For an overview of USGS information products, including maps, imagery, and publications, visit http://www.usgs.gov/pubprod

To order this and other USGS information products, visit http://store.usgs.gov

Any use of trade, firm, or product names is for descriptive purposes only and does not imply endorsement by the U.S. Government.

Although this information product, for the most part, is in the public domain, it also may contain copyrighted materials as noted in the text. Permission to reproduce copyrighted items must be secured from the copyright owner.

Suggested citation:

Corsi, S.R., Horwatich, J.A., Rutter, T.D., and Bannerman, R.T., 2013, Effects of best-management practices in Bower Creek in the East River priority watershed, Wisconsin, 1991-2009: U.S. Geological Survey Scientific Investigations Report 2012-5217, 21 p., at http://pubs.usgs.gov/sir/2012/5217/. 


\section{Acknowledgments}

The authors thank Jon Bechle, Bill Hafs, and other staff at the Brown County Land and Water

Conservation Department who provided land-use data, communication with land owners, and input on the interpretation of final results.

The authors also thank David Graczyk, John Walker, David Housner, Daniel Olson, and other colleagues at the U.S. Geological Survey for contributing to the data collection, data processing, and data analysis phases of the project. 
This page has been left blank intentionally. 


\section{Contents}

Abstract
Introduction
Purpose and Scope
Physical Setting and Land Use
Hydrologic Conditions During the Study Period
Water Quality Before and After Installation of Best-Management Practices
Constituent Concentrations at Base Flow
Storm Loads
Effects of BMPs on Water Quality

\section{Figures}

1. Map showing location of the Bower Creek Watershed and data-collection sites in

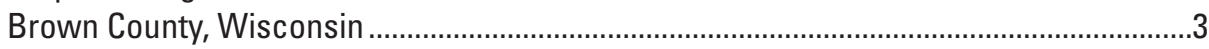

2. Map showing land use and land cover from 1986 in the Bower Creek Watershed,

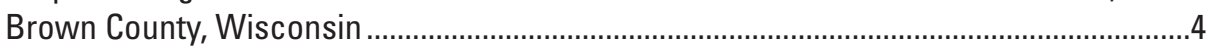

3. Map showing soil types in the Bower Creek Watershed, Brown County, Wisconsin .......5

4. Map showing animal-waste management, streambank protection, and grass waterways implemented during the study period in the Bower Creek Watershed, Brown County, Wisconsin...

5. Graphs showing yearly precipitation throughout the study period and long-term average yearly precipitation at Green Bay and Kewaunee, Wisconsin .............................

6. Graph showing cumulative rainfall distributions for the pre- and post-BMP (best-management practices) implementation period at Bower Creek, Brown County, Wisconsin

7. Graphs showing annual streamflow, base flow, and stormflow at Bower Creek, Brown County, Wisconsin, for water years 1991-1997 and 2006-2009...

8. Graph showing average monthly distribution of streamflow and total suspended solids, total phosphorus, and dissolved ammonia-nitrogen loads at Bower Creek, Brown County, Wisconsin, water years 1991-1997 and 2006-2009..

9. Graph showing average relative annual contributions of stormflow and base-flow periods to streamflow, total suspended solids, total phosphorus, and dissolved ammonia-nitrogen loadings at Bower Creek, Brown County, Wisconsin, for water years 1991-1997 and 2006-2009

10. Graphs showing average monthly streamflow and loads of total suspended solids, total phosphorus, and dissolved ammonia nitrogen during base-flow and stormflow periods, expressed as a percentage of the annual total water volume and constituent loads at Bower Creek, Brown County, Wisconsin. 
11. Graphs showing concentrations and water-year medians of total suspended solids, total phosphorus, and dissolved ammonia nitrogen in base-flow samples throughout the study period at Bower Creek, Brown County, Wisconsin

12. Photographs showingexamples of $A$, a dead furrow and $B$, an unaddressed concentrated flow area in the Bower Creek Watershed, Brown County, Wisconsin ....19

\section{Tables}

1. Summary of targeted and implemented rural best-management practices in the Bower Creek Watershed, Brown County, Wisconsin.

2. Results of Wicoxon rank-sum test for differences between constituent concentrations in base-flow samples from pre- and post-BMP implementation periods at Bower Creek, Brown County, Wisconsin.

3. Regression results for storm loads from rainfall periods at Bower Creek, Wisconsin

4. Median and mean rainfall-period storm loads and results of the Wilcoxon rank-sum test comparing storm-load residuals for pre- and post-BMP periods at Bower Creek, Wisconsin

\section{Conversion Factors and Datum}

\begin{tabular}{|c|c|c|}
\hline Multiply & By & To obtain \\
\hline \multicolumn{3}{|c|}{ Length } \\
\hline inch (in.) & 25.4 & millimeter (mm) \\
\hline foot (ft) & 0.3048 & meter $(\mathrm{m})$ \\
\hline mile (mi) & 1.609 & kilometer $(\mathrm{km})$ \\
\hline \multicolumn{3}{|c|}{ Area } \\
\hline acre & 0.4047 & square hectometer $\left(\mathrm{hm}^{2}\right)$ \\
\hline square mile $\left(\mathrm{mi}^{2}\right)$ & 2.590 & square kilometer $\left(\mathrm{km}^{2}\right)$ \\
\hline \multicolumn{3}{|c|}{ Flow rate } \\
\hline cubic foot per second $\left(\mathrm{ft}^{3} / \mathrm{s}\right)$ & 0.02832 & cubic meter per second $\left(\mathrm{m}^{3} / \mathrm{s}\right)$ \\
\hline \multicolumn{3}{|c|}{ Mass } \\
\hline pound, avoirdupois (lb) & 0.4536 & kilogram $(\mathrm{kg})$ \\
\hline ton per day (ton/d) & 0.9072 & metric ton per day \\
\hline \multicolumn{3}{|c|}{ Hydraulic gradient } \\
\hline foot per mile ( $\mathrm{ft} / \mathrm{mi})$ & 0.1894 & meter per kilometer $(\mathrm{m} / \mathrm{km})$ \\
\hline
\end{tabular}

Temperature in degrees Celsius $\left({ }^{\circ} \mathrm{C}\right)$ may be converted to degrees Fahrenheit $\left({ }^{\circ} \mathrm{F}\right)$ as follows:

$$
{ }^{\circ} \mathrm{F}=\left(1.8 \times^{\circ} \mathrm{C}\right)+32
$$

Concentrations of chemical constituents in water are given in milligrams per liter (mg/L)

A water year is defined as the 12-month period from 0ctober 1 for any given year, through September 30 of the following year. The water year is designated by the calendar year in which it ends. 


\title{
Abbreviations
}

\author{
BMP best-management practices \\ El erosivity index \\ GIS geographic information system \\ NOAA National Oceanic and Atmospheric Administration \\ USGS U.S. Geological Survey \\ USLE Universal Soil Loss Equation \\ WDNR Wisconsin Department of Natural Resources
}


This page has been left blank intentionally. 


\title{
Effects of Best-Management Practices in Bower Creek in the East River Priority Watershed, Wisconsin, 1991-2009
}

\author{
By Steven R. Corsi,, Judy A. Horwatich, ${ }^{1}$ Troy D. Rutter, and Roger T. Bannerman ${ }^{2}$
}

\section{Abstract}

Hydrologic and water-quality data were collected at Bower Creek during the periods before best-management practices (BMPs), and after BMPs were installed for evaluation of water-quality improvements. The monitoring was done between 1990 and 2009 with the pre-BMP period ending in July 1994 and the post-BMP period beginning in October 2006. BMPs installed in this basin included streambank protection and fencing, stream crossings, grade stabilization, buffer strips, various barnyard-runoff controls, nutrient management, and a low degree of upland BMPs. Water-quality evaluations included base-flow concentrations and storm loads for total suspended solids, total phosphorus, and ammonia nitrogen. The only reductions detected between the base-flow samples of the pre- and post-BMP periods were in median concentrations of total phosphorus from baseflow samples, but not for total suspended solids or dissolved ammonia nitrogen. Differences in storm loads for the three water-quality constituents monitored were not observed during the study period.

\section{Introduction}

Nonpoint-source contamination is a primary contributor to water resource quality problems in Wisconsin. In recognition of the importance of nonpoint sources, the Wisconsin Nonpoint Source Water Pollution Abatement Program (Nonpoint Program) was enacted in 1978 (Wisconsin Department of Natural Resources, 1978). When first introduced, the Nonpoint Program identified problems in 130 of the 330 watersheds in Wisconsin. For a given watershed, various management options - termed best-management practices (BMPs) — were available for funding support through the Nonpoint Program. For example, practices in rural areas included conservation tillage, contour stripcropping, streambank protection, and various barnyard-runoff controls. The Nonpoint Program provided matching funds to landowners for voluntary implementation of various BMPs using priority watersheds as a preference for consideration.

Until the late 1980s, little data existed to demonstrate the effectiveness of BMPs for improving water quality in Wisconsin's priority watersheds. The Wisconsin Department of Natural Resources (WDNR) and U. S. Geological Survey (USGS) developed and began a comprehensive, multidisciplinary evaluation-monitoring program in water year 1989 to assess the effectiveness of the Wisconsin Nonpoint Source Program (Wierl and others, 1996). This evaluationmonitoring program includes biological and stream-habitat monitoring by the WDNR and water-quality monitoring by the USGS. Eight watersheds were chosen for the evaluationmonitoring program. These watersheds were chosen because WDNR and Land County Conservation District personnel felt that a potential for substantial improvement existed and because BMPs were scheduled to be installed within the project timeframe. Results from five of these watersheds, which included Brewery and Garfoot creeks in the Black Earth Creek Watershed (Graczyk and others, 2003), Otter Creek in the Sheboygan River Watershed (Corsi and others, 2005) and Joos Valley and Eagle Creeks in the Waumundee River Watershed (Graczyk and others, 2012) were published previously.

This report presents results from Bower Creek, the sixth watershed where evaluation monitoring has been completed. The Bower Creek Watershed is a subbasin of the East River located in eastern Wisconsin near DePere, Wisconsin. The monitoring for Bower Creek occurred from September 1990 through January 1995, April 1996 through June 1997, and October 2006 through September 2009. Streamflow and water-quality data were collected continuously at one station approximately 7 miles (mi) upstream from the confluence with the East River.

${ }^{1}$ U.S. Geological Survey

${ }^{2}$ Wisconsin Department of Natural Resources 


\section{Purpose and Scope}

The overall objective of the WDNR and USGS evaluation-monitoring program was to evaluate BMP effectiveness in several small watersheds located in geographically and hydrologically diverse areas of Wisconsin.

This report summarizes the results of a study on effectiveness of watershed-management practices for controlling nonpoint-source contamination in the Bower Creek Watershed. Concentrations of total suspended solids, total phosphorus, and dissolved ammonia nitrogen in samples collected at base flow before BMP installation (pre-BMP) are compared and contrasted to those for the period after BMP installation (post-BMP). Pre-BMP storm loads of total suspended solids, total phosphorus, and dissolved ammonia nitrogen from sampled rainfall periods are compared and contrasted to the post-BMP storm loads.

Data-collection periods were from September 1990 through March 1995, April 1996 through June 1997, and October 2006 through September 2009. Installation of BMPs began in 1996. To satisfy statistical requirements to keep the number of data points in the pre- and post-BMP implementation periods similar, July 1994 was used as the end of the pre-BMP implementation period. In October, 2006, most of the BMP installation that was planned for this program was complete in the watershed. Monitoring after this time was considered to be the post-BMP period. For the purpose of this study, the post-BMP period is considered to be October 2006 through September 2009.

\section{Physical Setting and Land Use}

Bower Creek is a tributary to the East River in Brown County about $5 \mathrm{mi}$ east of the city of DePere, Wisconsin (Wis.) (fig. 1). Bower Creek has been classified by the WDNR as a warm-water forage stream that has the potential to maintain a forage fish population capable of supporting an abundant, diverse community of forage fish and other aquatic life (Wisconsin Department of Natural Resources, 1993). Bower Creek drains 14.8 square miles $\left(\mathrm{mi}^{2}\right)$ upstream from the stream-gaging station, and the total stream channel length, which is all intermittent, is $37.1 \mathrm{mi}$ from the station to the stream headwaters. The watershed contains several small lakes and ponds.

Total land use and land cover for Bower Creek in the beginning of the study is shown in figure 2. In the Bower Creek Watershed, cropland (83.1 percent) dominated the land use and land cover, with woodlots ( 6 percent) being the next greatest land use and land cover. In all, 115 farms were included or partially included in the Bower Creek Watershed. The average farm size was 120 acres. There were 41 barnyards in the watershed with an average herd size of 118 animals, of which 97 percent are dairy cows (Rappold and others, 1997). According to Brown County Land and Water Conservation Department, the number of livestock in the watershed and the cropland percentage has not changed substantially throughout the monitoring period, but exact numbers were not available. Data collected by Brown County indicate the soil phosphorus levels to be 50 to more than 100 parts per million for several fields in the Bower Creek Watershed (Kelling and others, 2003).

The overall channel slope of Bower Creek is 11 feet per mile (ft/mi). The bed material consists mainly of sand, silt, and clay with gravel and bedrock in riffle areas. The soil types in the Bower Creek watershed vary spatially and consist mainly of soil categories from silt loams to silty clay loams (fig. 3). These soils are poorly drained unless a tile system is used (Link and others, 1974).

\section{Methods}

Watersheds can be affected in numerous ways by changes in land use and land management brought about by BMP installation. A suite of different variables were considered in an attempt to understand these effects. Hydrologic, waterquality, and land-use data were the chosen areas of study considered to be important for this evaluation. Not only are the areas of study important in this evaluation, but the exact methods of data collection and analysis are essential in detecting changes resulting from BMP installation. A description of data collection and analysis methods for each of these areas of study are included in this section.

\section{Hydrologic and Water-Quality Data-Collection Network}

A stream-gaging station equipped for continuous recording of data was installed in September 1990 at Bower Creek (fig. 1). Stage was measured with a bubblertype pressure transducer every 5 minutes during periods of increased runoff and every hour otherwise. Streamflow measurements were made according to standard USGS methods (Rantz and others, 1982) every 4 to 6 weeks, and more frequently during high flows, to define the stage-streamflow relation used to compute continuous streamflow record.

The stream-gaging station was equipped with a stageactivated refrigerated water sampler for automatic collection of water samples during periods of increased runoff from rainfall or snowmelt. The data logger was programmed to initiate sampling once the stream stage reached an initial sampling threshold. As stage increased, samples were collected with each 0.2-foot (ft) increase in stage; as stage decreased, samples were collected with each 0.3 -ft decrease in stage. The sampling strategy was designed to collect more samples during increasing stage, when the concentration of the constituents of interest would likely be changing most rapidly. After a sampling event, the samples were collected from the gaging station, chilled on ice in coolers, processed at the 


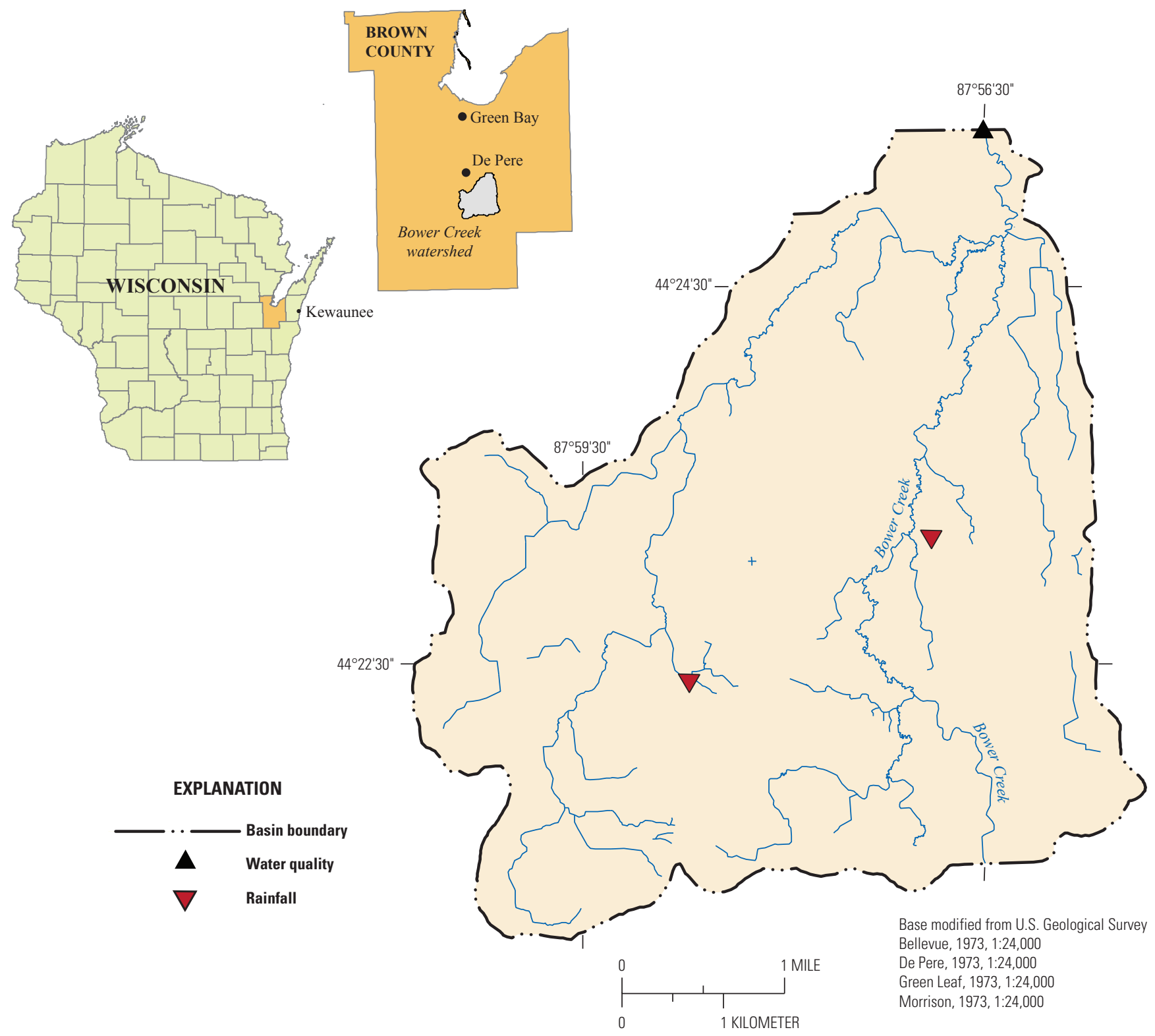

Figure 1. Location of the Bower Creek Watershed and data-collection sites in Brown County, Wisconsin. 
Percentage of total land use and land cover

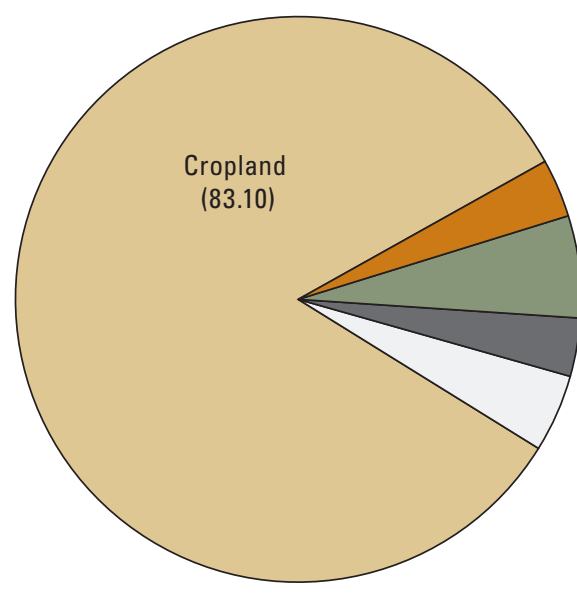

Farmstead (3.30)

Woodlot (6.00)

Road (3.20)

Other* $(4.40)$

*Includes pasture, grassland, grazed woodlot, open water, wetland, and residential categories

\section{EXPLANATION}

Land use and land cover type

Cropland

Pasture

Grassland

Woodlot

Grazed woodlot

Open water

Wetland

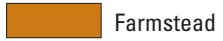

Residential

Road

Basin boundary

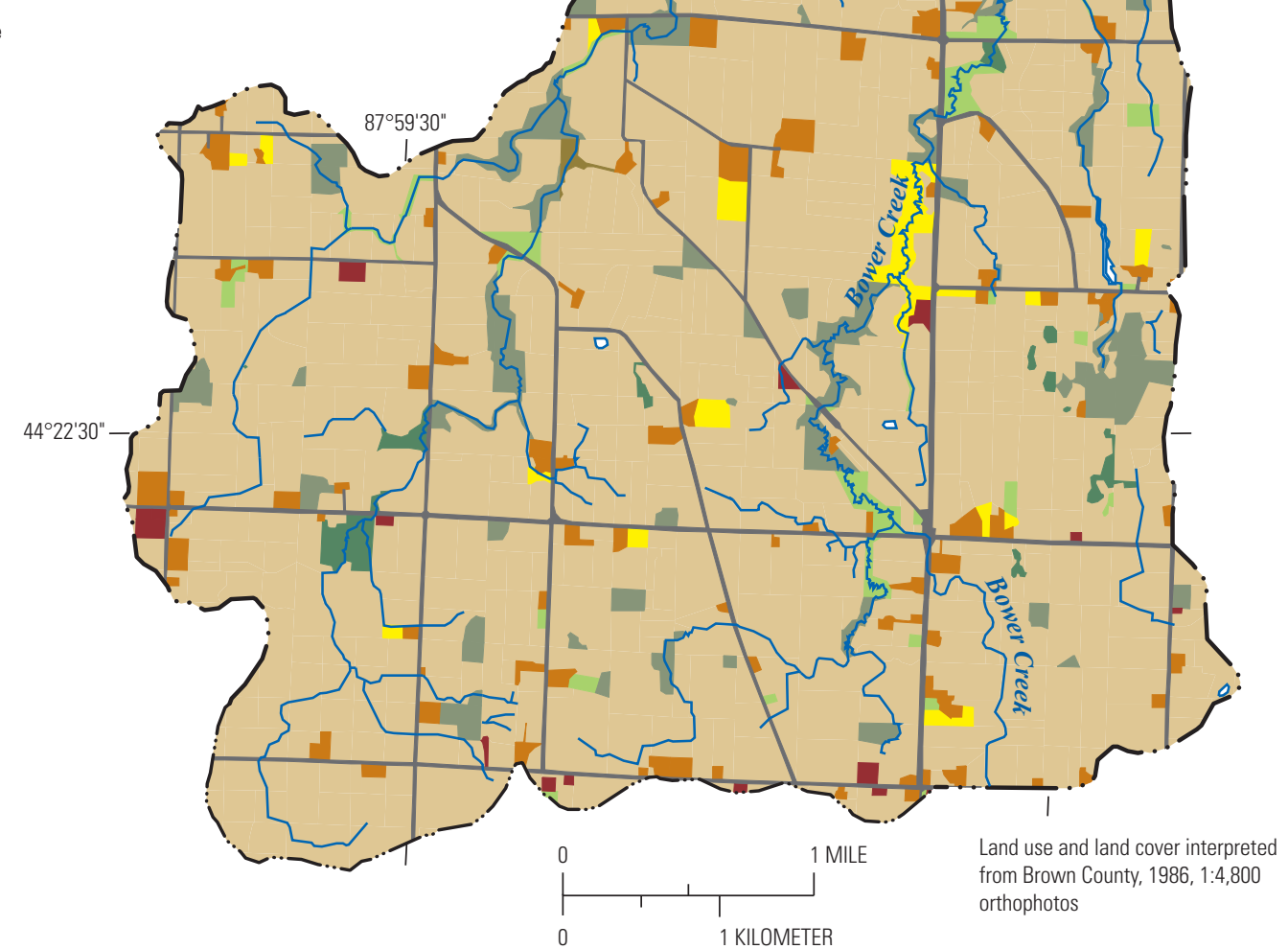

Figure 2. Land use and land cover from 1986 in the Bower Creek Watershed, Brown County, Wisconsin. 


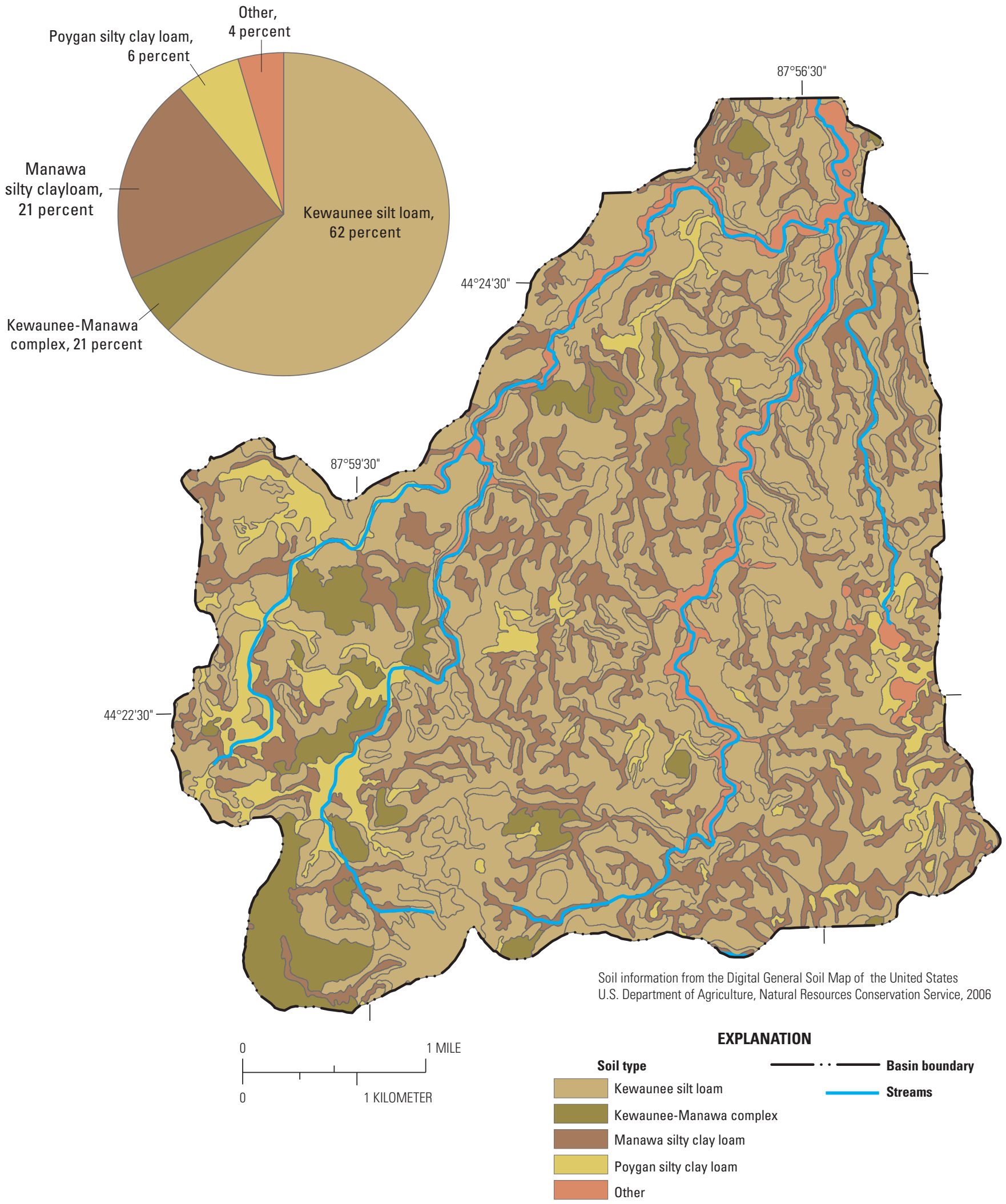

Figure 3. Soil types in the Bower Creek Watershed, Brown County, Wisconsin. 
USGS field office, and then transported to the Wisconsin State Laboratory of Hygiene to be analyzed for total suspended solids, total phosphorus, and dissolved ammonia nitrogen as nitrogen using standard methods (Wisconsin State Laboratory of Hygiene, 1992; American Public Health Association, 1989, 1992). Values for TSS and ammonia-nitrogen were censored based on the analytical detection levels. The detection levels for TSS were $2 \mathrm{mg} / \mathrm{L}$ before September 1994, and $5 \mathrm{mg} / \mathrm{L}$ after September 1994. The detection levels for ammonia-nitrogen were $0.027 \mathrm{mg} / \mathrm{L}$ before 1998 and $0.015 \mathrm{mg} / \mathrm{L}$ after 1998 . Samples collected were selected for analysis to represent variation in water quality over a range of increasing and decreasing stages.

In addition to the automated samples, manual samples were collected at a fixed interval. The fixed interval during the sampling periods was approximately every 2 weeks in the spring, summer, and fall, and once a month in the winter. Samples were integrated over the depth and width of the stream by use of a hand-held sampler (Edwards and Glysson, 1988). The fixed-interval samples also were analyzed for total suspended solids, total phosphorus, and dissolved ammonia nitrogen.

Rainfall was measured throughout the study period at three locations within the watershed (fig. 1). One rain gage was at the stream-gage location, and the other two rain gages were sited by trial and error to result in approximately equal Thiessen polygon areas. Thiessen polygons represent the areas in closest proximity to each rain gage; the average rainfall was computed as a weighted average using the Thiessen polygon areas as the weighting factor (Viessman and others, 1977). Rainfall was collected in an 8 -inches (in). collector that drained into a tipping bucket rain gage. Each tip represented 0.01 in. of rain; all rainfall data were recorded every 5 minutes. Rain gages were calibrated annually.

\section{Selection and Inventory of Watersheds}

Inventory of the rural watersheds began in 1992 to provide information on land-use and land-treatment changes that may affect water quality. A geographic information system (GIS) database contained the land-use and BMP inventories. Watershed boundaries, hydrography, roads, streams, woodlots, rain gages, and BMPs were digitized from 1:24,000 topographic maps. Farm-field and parcel mapping was done by the USGS staff by digitizing orthophotos. Detailed descriptions of each watershed and the BMP program were reported in Rappold and others (1997), and Wierl and others (1996).

Wisconsin's administrative rules to address the control of polluted runoff from rural areas are specified in the Wisconsin administrative code for natural resources, chapter NR120, "The Priority Watershed and Priority Lake Program." (Wisconsin Department of Natural Resources, 1978). The rules identify the most effective BMPs to control nonpoint pollutants. The state of Wisconsin could cost-share as much as 70 percent of the practices identified. The Priority Watersheds Program selected, assessed, and approved the East River project between 1985 and 1991. Bower Creek is in the East River Watershed and was administered under the East River Priority Watershed project. The voluntary signup period for BMPs started in March 1991 and lasted until February 2006. Monitoring of the post-BMP implementation began on October 1, 2006, after most practices were installed and operational.

Targeted and implemented BMPs for the Bower Creek Watershed are summarized in table 1. The initial BMP targets were determined by Brown County based on an assessment on potential water-quality effect in Bower Creek. Annual updates of practices - animal-waste management, streambank protection, and upland management - were obtained by contacting the Brown County Land Conservation Department. Animal-waste management systems are installed to reduce the amount of organic matter reaching the stream by improving the cattle lots and adding filter strips. Streambank protection reduces the amount of sediment reaching the stream by limiting cattle access and stabilizing streambanks by various practices, including fencing and installation of watering areas in the stream. Riparian buffer strips reduce erosion from the

Table 1. Summary of targeted and implemented rural bestmanagement practices in the Bower Creek Watershed, Brown County, Wisconsin.

[BMP, best-management practice]

\begin{tabular}{|c|c|c|}
\hline $\begin{array}{l}\text { Management } \\
\text { practice }\end{array}$ & Targeted & Implemented \\
\hline \multicolumn{3}{|c|}{ Animal-waste management } \\
\hline Manure storage (facilities) & 9 & 17 \\
\hline $\begin{array}{l}\text { Barnyard-runoff control systems } \\
\text { (facilities) }\end{array}$ & 32 & 16 \\
\hline $\begin{array}{l}\text { Milkhouse wastewater treatment } \\
\text { (facilities) }\end{array}$ & 2 & 2 \\
\hline \multicolumn{3}{|c|}{ Streambank protection } \\
\hline $\begin{array}{l}\text { Stream shaping, seeding and riprap } \\
\text { (feet) }\end{array}$ & 2,320 & 2,013 \\
\hline Fencing (feet) & 625 & 625 \\
\hline Stream crossing (numbers of crossings) & 1 & 1 \\
\hline Grade stablization (structures) & 0 & 1 \\
\hline Buffer strips (acres) & 0 & 16.4 \\
\hline \multicolumn{3}{|c|}{ Upland management $^{2}$} \\
\hline Nutrient management (acres) & 4,020 & 1,939 \\
\hline Upland BMPs (acres) & 4,480 & 1,564 \\
\hline \multicolumn{3}{|c|}{$\begin{array}{l}{ }^{1} \text { There were } 17 \text { other manure storage facilities implemented by previous } \\
\text { farm programs. }\end{array}$} \\
\hline $\begin{array}{l}{ }^{2} \text { Upland BMPs include change in crop ro } \\
\text { rea stabilization, grass waterways, and pas }\end{array}$ & reduce & lage, critical \\
\hline
\end{tabular}


land surface near the stream by limiting agricultural activities, providing more natural vegetation within a $25-35$ foot buffer from the streambank. Upland-management practices are designed to reduce the amount of sediment and nutrients delivered with runoff or subsurface drainage by cropland, manure, and fertilizer management. Upland-sediment and runoff control practices include change in crop rotation, reduced tillage, critical area stabilization, grass waterways, and pasture management.

In 2006, most of the BMP installation goals set by the WDNR and local Land Conservation Department had been achieved in the Bower Creek Watershed. Additional practices could be implemented for several years, but it was felt that many sources of nonpoint pollution had been controlled by the practices that had been implemented and there were no immediate plans to implement more BMPs for sources that were not controlled. The land-use tracking was discontinued in 2007 when the post-BMP monitoring phase ended. The status of barnyard and streambank protection practices as of 2009 is shown in figure 4 . The barnyard installations from before the study period and during the study period are distinguished by different symbols on this figure.

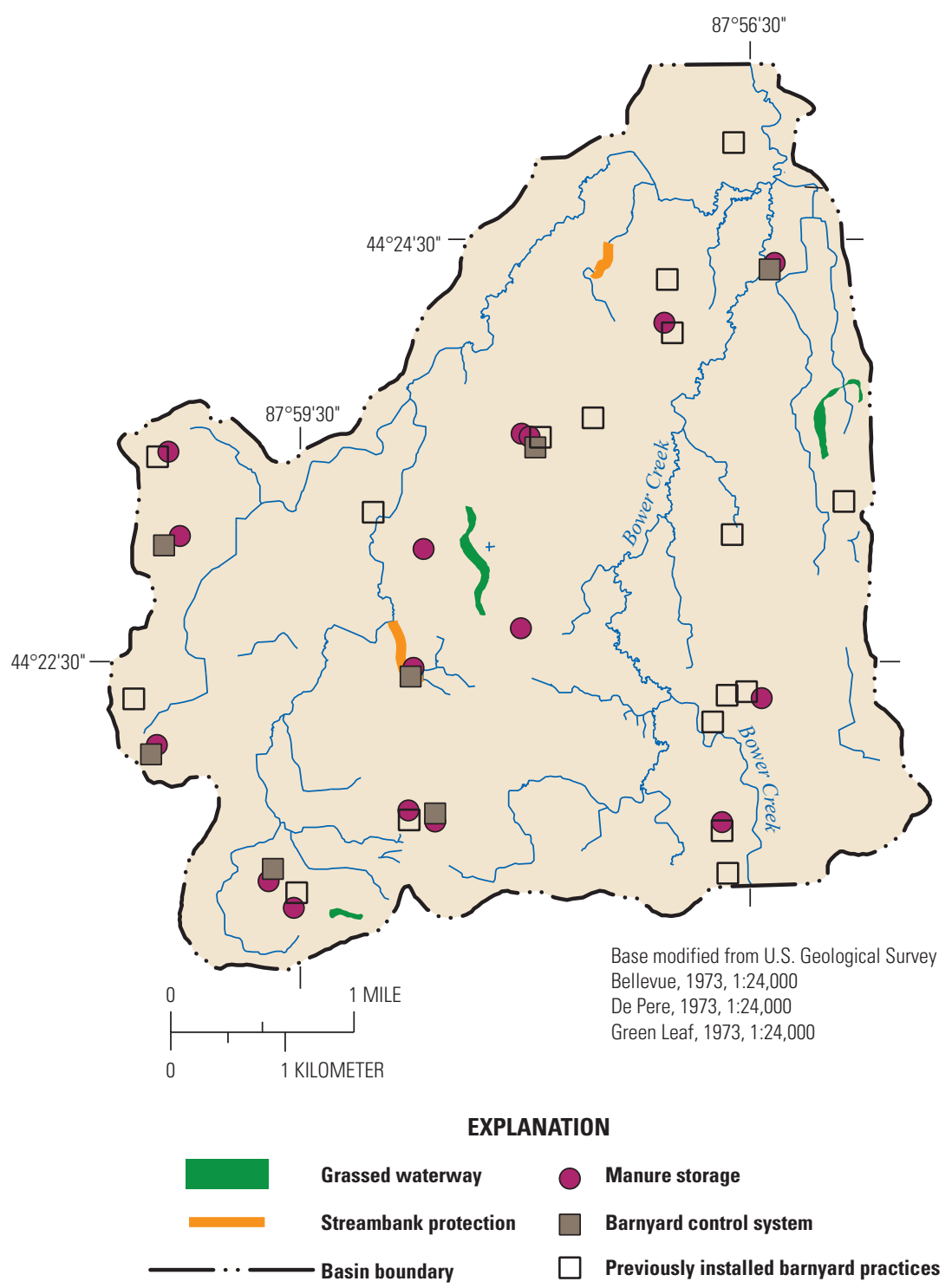

Figure 4. Animal-waste management, streambank protection, and grass waterways implemented during the study period in the Bower Creek Watershed, Brown County, Wisconsin. 


\section{Hydrologic Conditions During the Study Period}

Precipitation: The 30-year normal annual precipitation is 29.19 in. at the National Oceanic and Atmospheric Administration (NOAA) weather station in Green Bay, Wis., and 31.9 in. at the NOAA weather station in Kewaunee, Wis. (National Oceanic and Atmospheric Administration, 2010). Long-term averages from 1862 through 2009 are 31.8 in. at Green Bay (1886 through 2009) and 30.3 in. at Kewaunee (National Oceanic and Atmospheric Administration, 2010). Data collected at the NOAA gages indicate that precipitation during the study period was less than the long-term average for 2 of 3 years during the pre-implementation phase and 1 of 3 years during the post-implementation phase of the study (fig. 5). The largest deviation between annual precipitation and the long-term average was in calendar year 1993, when the precipitation was $36.51 \mathrm{in}$. at Green Bay and 38.03 in. at Kewaunee.

Monitored storms during the study period ranged in rainfall depth from 0.19 to $3.23 \mathrm{in}$. The median depth of rainfall of $0.79 \mathrm{in}$. from the monitored storms was less during the pre-BMP implementation period than 0.93 in. observed during the post-BMP implementation period. The distribution of rainfall depth from monitored storms during the preBMP implementation period indicates that the pre-BMP implementation-period storm depths were slightly less than those from the post-BMP implementation period (fig. 6).

Streamflow: Streamflow data were collected continuously during the study period and published each year in "Water Resources Data, Wisconsin" for water years 1991 through 1997 and 2007 through 2009 (Holmstrom and others, 1992-1998; U.S. Geological Survey, 2008-10). These data

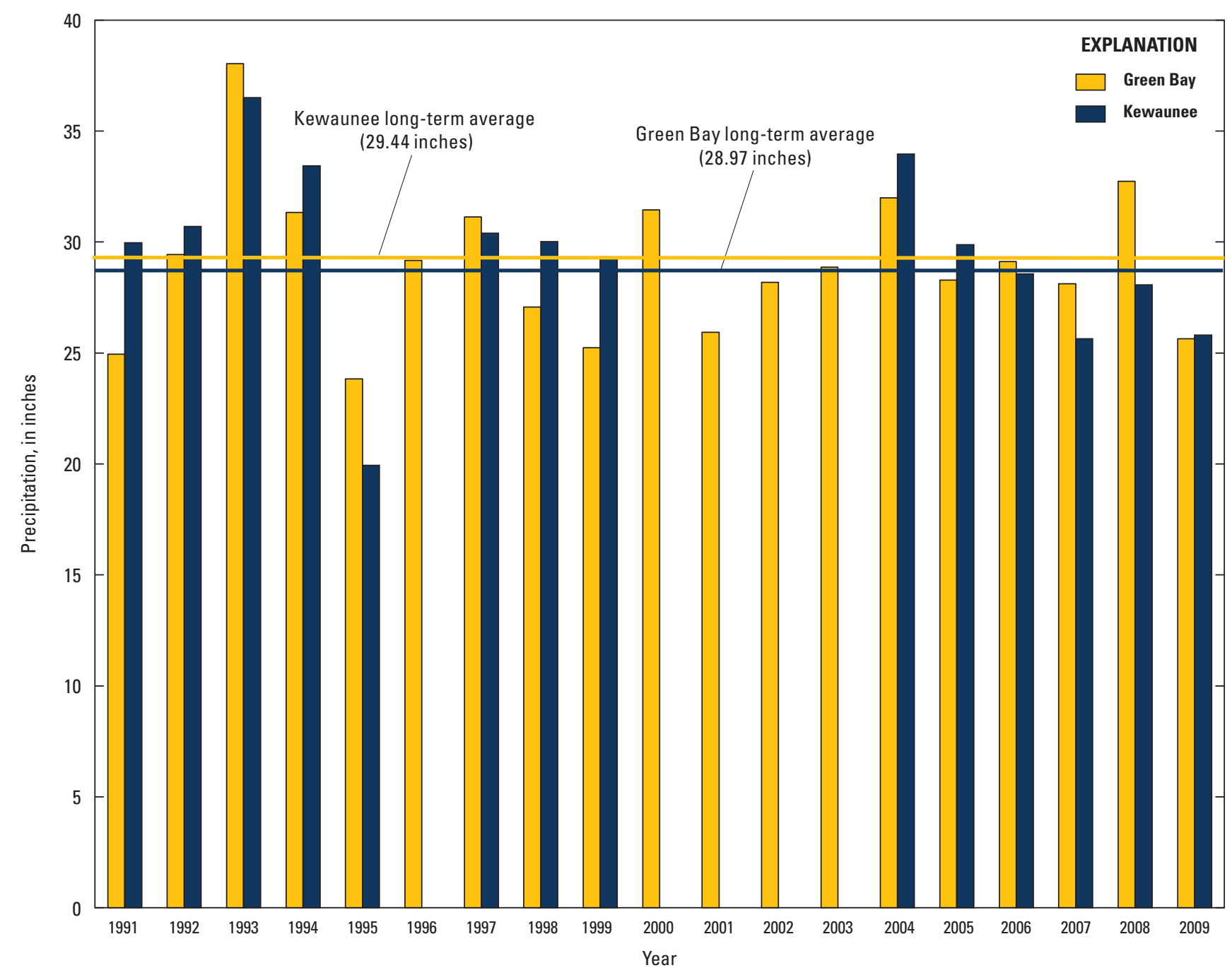

Figure 5. Yearly precipitation throughout the study period and long-term average yearly precipitation at Green Bay and Kewaunee, Wisconsin. 


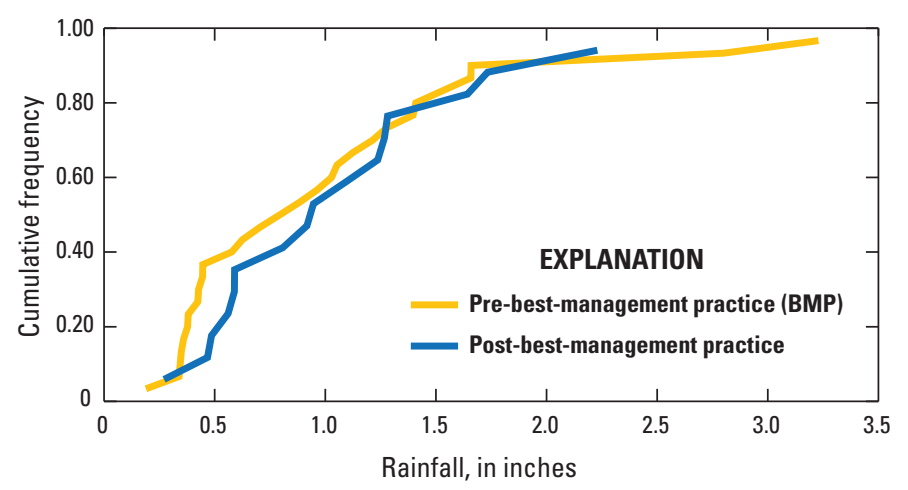

Figure 6. Cumulative rainfall distributions for the pre- and postBMP (best-management practices) implementation period at Bower Creek, Brown County, Wisconsin.

were used to determine streamflow characteristics and to compute nutrient and total suspended solids loads. In addition, daily mean base-flow contributions were separated from the daily mean streamflows (White and Sloto, 1990), and overland runoff (stormflow) was determined by computing the difference between daily mean streamflow and daily mean base flow. The mean annual streamflow at Bower Creek during the study period was $7.90 \mathrm{ft}^{3} / \mathrm{s}$, of which 36 percent was base flow (figs.7-9). The mean flow for the pre-BMP implementation period was $10.6 \mathrm{ft}^{3} / \mathrm{s}$ (37 percent base flow) and for the post-BMP implementation period was $6.1 \mathrm{ft}^{3} / \mathrm{s}$ (34 percent base flow). The greatest mean overall streamflow and base flow occurred in 1993 .

\section{Seasonal and Hydrologic Distribution of Loads:}

Daily mass loads were computed for total suspended solids, total phosphorus, and dissolved ammonia nitrogen for the monitoring period. These values were used to compute mean monthly loads to understand how the loads were distributed throughout the year (fig. 8). Additionally, streamflow and loads were separated into annual (fig. 9) and monthly (fig. 10) base-flow and stormflow contributions.

Overall, the largest contributions of streamflow and loadings occur in March, April, June, and July, but there is some variability in this conclusion among different constituents. A summary of the main seasonal and hydrologic patterns observed in these data are as follows:

- Streamflow: Total streamflow contributions during March, April, and June accounted for 68 percent of annual streamflow, 54 percent of which was in March and April. Streamflow was lowest from August through October. Average annual stormflow contribution was nearly double that from base-flow periods. Average monthly stormflow contributions were greater than or nearly the same as those from base-flow periods for all months. The peaks of base-flow and stormflow volumes occurred in March and April with a secondary peak in June.
- Total suspended solids loadings: Total suspended solids loadings during April were 29 percent, and June and July accounted for 55 percent of the annual loadings. Average annual total suspended solids loadings were dominated by stormflow periods ( 92 percent) as compared to base-flow periods. Average monthly contributions of total suspended solids loads were greater during stormflow periods than during baseflow periods in all months except January. The greatest stormflow contributions occurred during March, April, June, and July.

- Total phosphorus loadings: Total phosphorus from March, April, and June accounted for 72 percent of annual loadings, of which 56 percent was in March and April. Average annual total phosphorus loadings were greater during stormflow periods (79 percent) than during base-flow periods. Average monthly loads were greater during stormflow periods than during base-flow periods for all months.

- Dissolved ammonia nitrogen loadings: Dissolved ammonia nitrogen from March and April accounted for 68 percent of annual loadings. Average annual dissolved ammonia-nitrogen loadings were greater during stormflow periods ( 68 percent) than during base-flow periods. Average monthly loadings were dominated by the months of March and April, with base-flow contributions of 28 percent and stormflow contributions of 40 percent of the mean annual load during those 2 months. Stormflow loadings were also greater during all other months of the year as well.

The distribution of average monthly loads and average annual loads suggests that different constituents exhibit different behaviors depending on their particulate and dissolved fractions. Total suspended solids consists of 100 percent particulate matter, total phosphorus is comprised of particulate and dissolved fractions, and dissolved ammonia nitrogen is completely in solution. Total suspended solids loads are dominated by stormflow; total phosphorus loads are greater in stormflow, but base flow is more influential than for total suspended solids; and dissolved ammonia-nitrogen loads are greater in stormflow, but still more affected by base flow than total phosphorus. These data suggest that the loadings for constituents containing particulate fractions are greater during stormflow, and loadings for constituents containing dissolved fractions have increased loadings during base flow. With this information and the monthly load data, it is apparent that the transport mechanisms and sources of these three constituents vary to some degree. Two primary pathways from sources to the stream are through surface runoff and groundwater discharge. The pathway of total suspended solids would be limited mainly to surface runoff, whereas the dissolved fractions of total phosphorus and ammonia nitrogen can also be transported through the shallow groundwater system and 

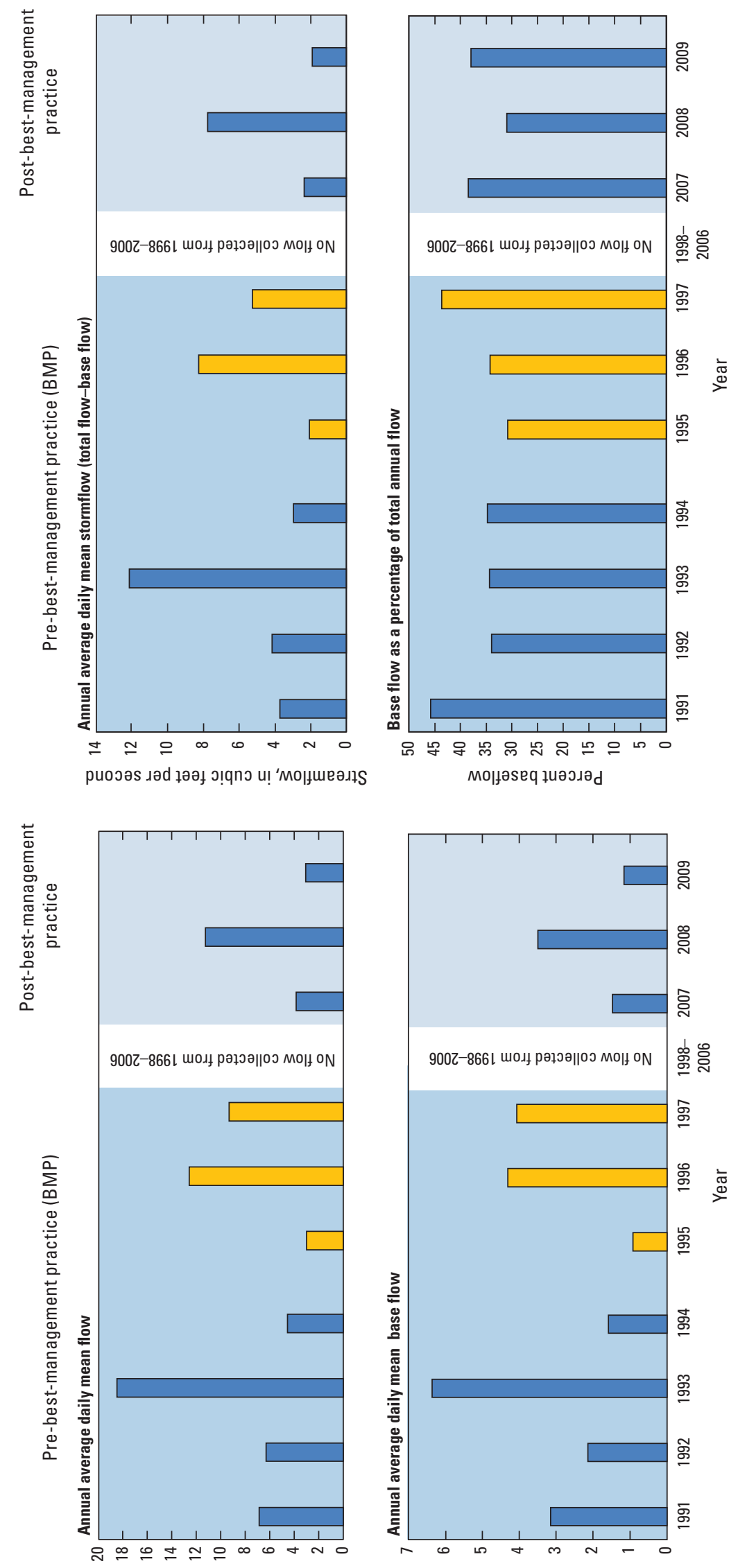

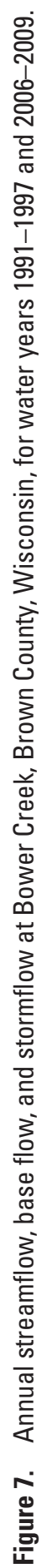




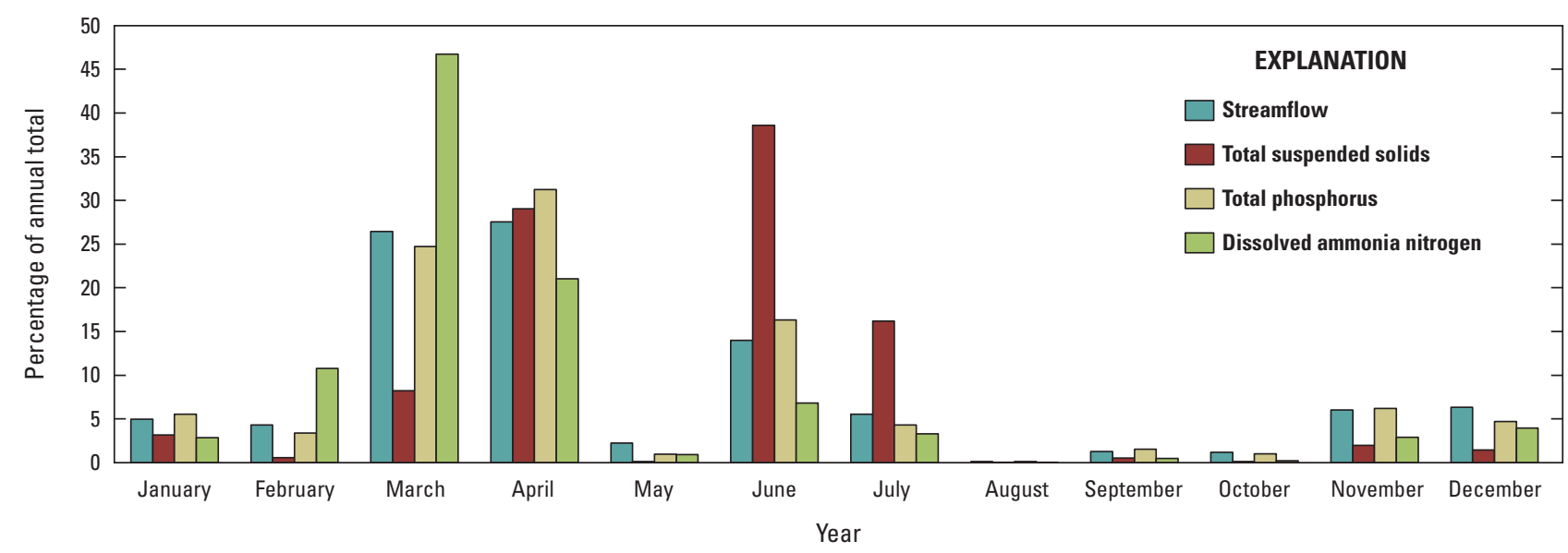

Figure 8. Average monthly distribution of streamflow and total suspended solids, total phosphorus, and dissolved ammonianitrogen loads at Bower Creek, Brown County, Wisconsin, water years 1991-1997 and 2006-2009.

discharged to the stream in base flow. Solids tend to settle out more during base-flow periods because stream velocities are less during these periods than during storms.

Higher concentrations and loads of dissolved ammonia nitrogen in winter could have several contributing factors. Winter spreading of manure on crop lands may result in greater concentrations and loads because infiltration and movement in the soil would be reduced on frozen ground, microbial organisms needed for oxidation of ammonium would not be as active in cold winter and spring temperatures, and contact with soils that have the potential to remove ammonium from the manure-affected runoff while it migrates into groundwater or to drain tiles would be reduced. In general, the applied manure is more likely to reach the stream because of these conditions during stormflow periods for runoff. Loads and flows are also greatest for base-flow periods in March and April. Soils are typically at a high level of saturation during these months, leading to increased base flow levels that would also generate increased loadings of ammonia nitrogen.

The implications of this information on identifying sources of individual constituents are as follows: Total suspended solids contributions would be greatest from areas of active surface runoff; land uses that promote infiltration would decrease total suspended solids loads. Total phosphorus and dissolved ammonia nitrogen would be greatest from areas of active surface runoff, but the dissolved fraction could also enter the stream through infiltration and subsequent groundwater subsurface drainage transport such as tiles to the stream; land uses that promote infiltration would reduce the phosphorus and dissolved ammonia-nitrogen load during surface-runoff periods but may or may not change the total phosphorus and dissolved ammonia-nitrogen load during base-flow periods. In addition, dissolved phosphorus may be introduced by desorption from sediments in the stream channel.

These results are not unique in this region of Wisconsin. Data collected in a companion project at Otter Creek in Sheboygan Co., Wis., resulted in similar conclusions regarding seasonal distribution of loads (Corsi and others, 2005). The largest contributions of all three constituents in Otter Creek were from February through April with a secondary peak of total suspended solids and total phosphorus in June and July. Contributions from storm periods were greater than that from base-flow periods for total suspended solids and total phosphorus, but base-flow and stormflow contributions for

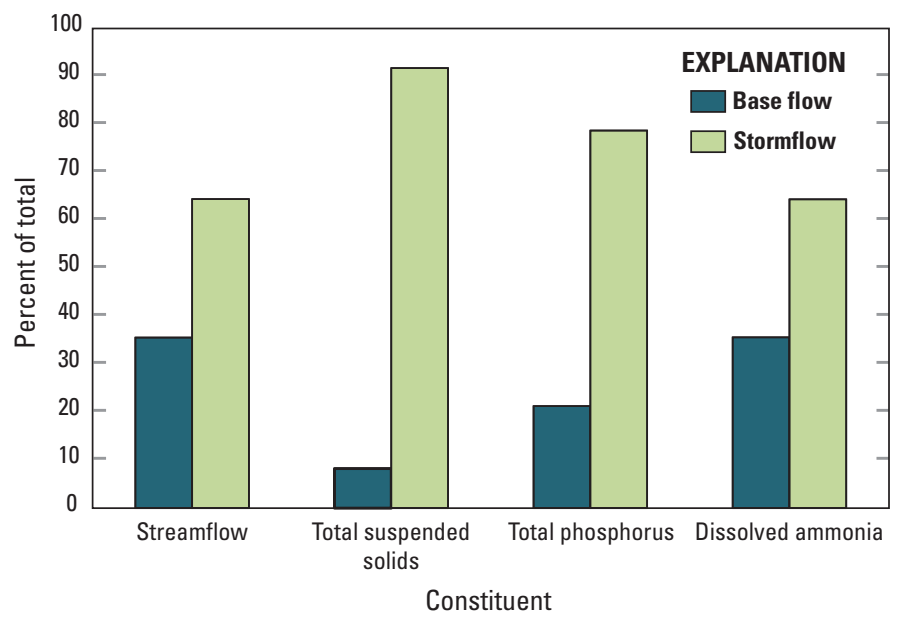

Figure 9. Average relative annual contributions of stormflow and base-flow periods to streamflow, total suspended solids, total phosphorus, and dissolved ammonia-nitrogen loadings at Bower Creek, Brown County, Wisconsin, for water years 1991-1997 and 2006-2009. 

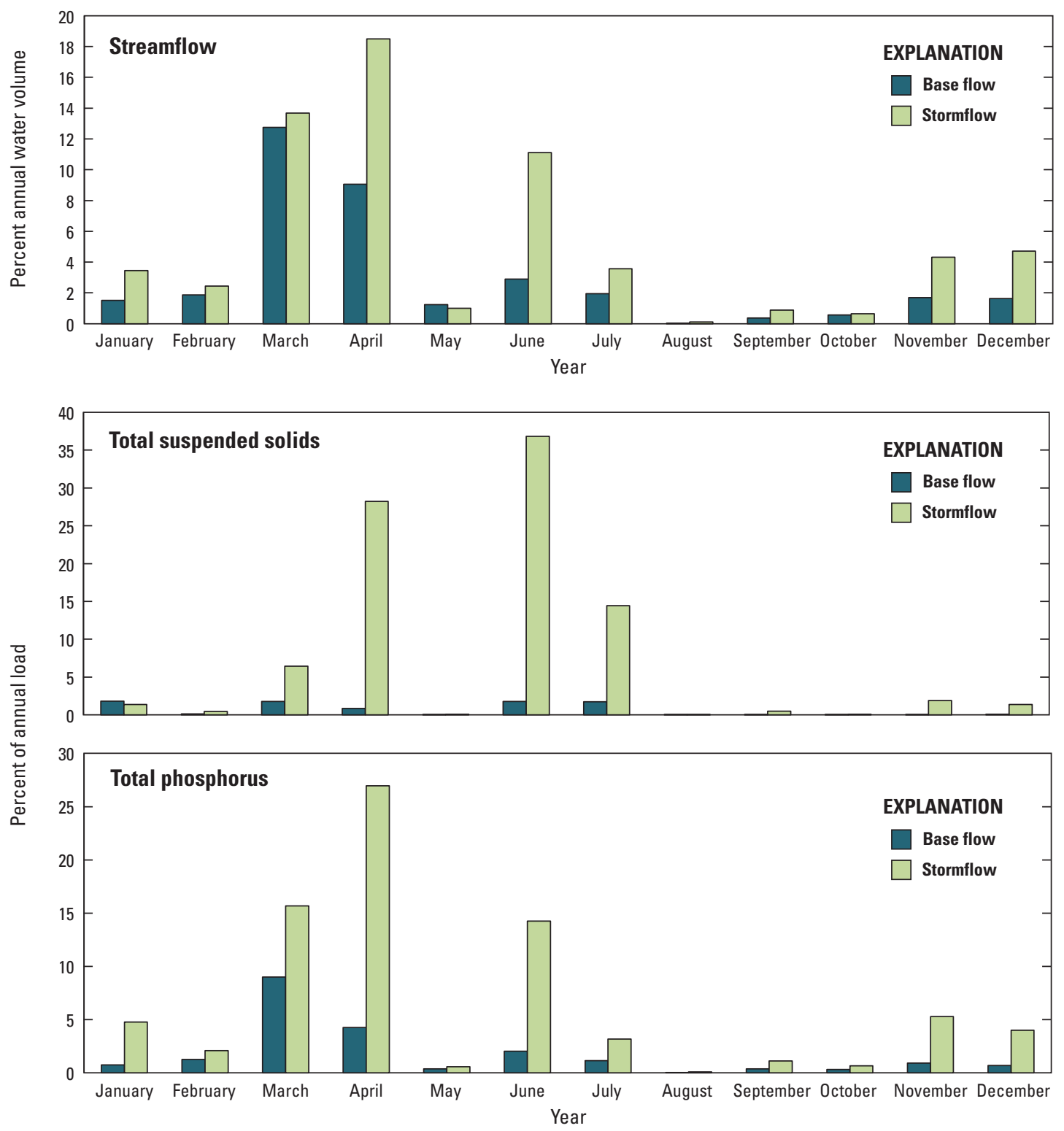

Figure 10. Average monthly streamflow and loads of total suspended solids, total phosphorus, and dissolved ammonia nitrogen during base-flow and stormflow periods, expressed as a percentage of the annual total water volume and constituent loads at Bower Creek, Brown County, Wisconsin. 
dissolved ammonia nitrogen were nearly equal. A broader study of small watersheds throughout Wisconsin included examination of total suspended solids and total phosphorus loads in different ecoregions (Danz and others, 2010). Results were more variable than Otter and Bower Creek, but still indicated that load contributions were greatest from late winter to early summer except for August-September peaks of total suspended solids in the Northern lakes and Forests/North Central Hardwoods region. Similar to Otter Creek and Bower Creek, stormflow contributions exceeded that of base-flow contributions of total suspended solids and total phosphorus.

\section{Water Quality Before and After Installation of Best-Management Practices}

The primary objective of this study was to evaluate overall BMP effectiveness at the watershed scale. BMPs installed in the Bower Creek Watershed over the course of the study can potentially affect the stream in numerous different ways. Changes in water chemistry were evaluated using results from base-flow sampling and also by evaluating storm loads from rainfall periods. Land-use data were used to interpret results from these analyses and to help understand the effects of individual BMP types.

\section{Constituent Concentrations at Base Flow}

Base flow in Bower Creek consists of groundwater contributions, including that from drain tiles. Water-quality sample results from base-flow concentrations, therefore, will reflect groundwater discharges, and direct surface effect and in-stream processes. Consequently, base-flow water quality may be affected by some land-use practices in the watershed that affect direct surface influences (such as streambank protection) and others that affect infiltration to ground water (such as filter strips).

Fixed-interval water-quality samples were collected throughout the pre- and post-BMP implementation periods. Base-flow samples were separated from the fixed-interval samples for use in subsequent data analysis. Base-flow samples were identified by use of a combination of techniques. First, daily mean streamflow was separated into base-flow and overland-runoff components. For any given fixed-interval sample, if the ratio of instantaneous discharge to daily mean base flow was less than or equal to 0.95 , that sample was considered to be a potential base-flow sample. In addition, an estimation of the time lag for overland runoff in the watershed was computed as the drainage area in square miles raised to the exponent 0.2 (Viessman and others, 1977). The overlandrunoff time lag was estimated to be 1.7 days for Bower Creek, so potential base-flow samples that were collected within 1.7 days of the peak of a hydrograph were not considered to be base-flow samples.

During the study, a total of 56 samples for total suspended solids, 56 samples for total phosphorus, and 53 samples for dissolved ammonia nitrogen were collected during conditions that qualified as base flow (fig. 11).

Statistical analyses (Wilcoxon rank-sum test) were used to test for significant differences between base-flow results from samples collected during the pre- and post-BMP implementation periods (Helsel and Hirsch, 1992). Results of the Wilcoxon rank-sum nonparametric test indicate significant differences at the 95-percent confidence level between preand post-BMP base-flow concentrations for total phosphorus but not for total suspended solids and dissolved ammonia nitrogen (table 2).

The lack of significant change in ammonia-nitrogen concentrations during base flow in Bower Creek is similar to results from all but one (Garfoot Creek) of the other Whole Stream Monitoring watersheds.

\section{Storm Loads}

Because much of the annual total suspended-solids and nutrient transport occurs during storms, fixed-interval sampling - particularly at a monthly frequency - may not indicate changes resulting from BMP implementation (Walker, 1993). Consequently, mass transport resulting from individual rainfall storms was analyzed. Stream water was sampled numerous times per storm for each storm used in the analysis (average of 10 samples per storm, minimum of 2 samples per storm, and maximum of 32 samples per storm). Instantaneous mass transport of a particular constituent was determined by multiplying streamflow by the concentration of the constituent and a conversion factor (Porterfield, 1972). The integration method was then used to determine the mass transport of each constituent for each storm (Porterfield, 1972), expressed as a storm load. Concentration at the beginning of a storm was estimated from samples collected during previous base-flow periods between storms. Concentration at the end of the storm was estimated from samples collected immediately after the end of the storm. Some concentration data for individual storms were estimated by the relation between concentration and streamflow. Estimated data within a storm period were kept to a minimum.

Variability in storm loads caused by differences in rainfall, temporal land surface variability, and other processes can be large enough to mask potential differences in the pre- and post-BMP implementation periods. In addition, because the pre- and post-BMP implementation periods arise from different hydrologic conditions, differences in the hydrologic conditions could result in differences that are not a result of the management practices. For these reasons, one 

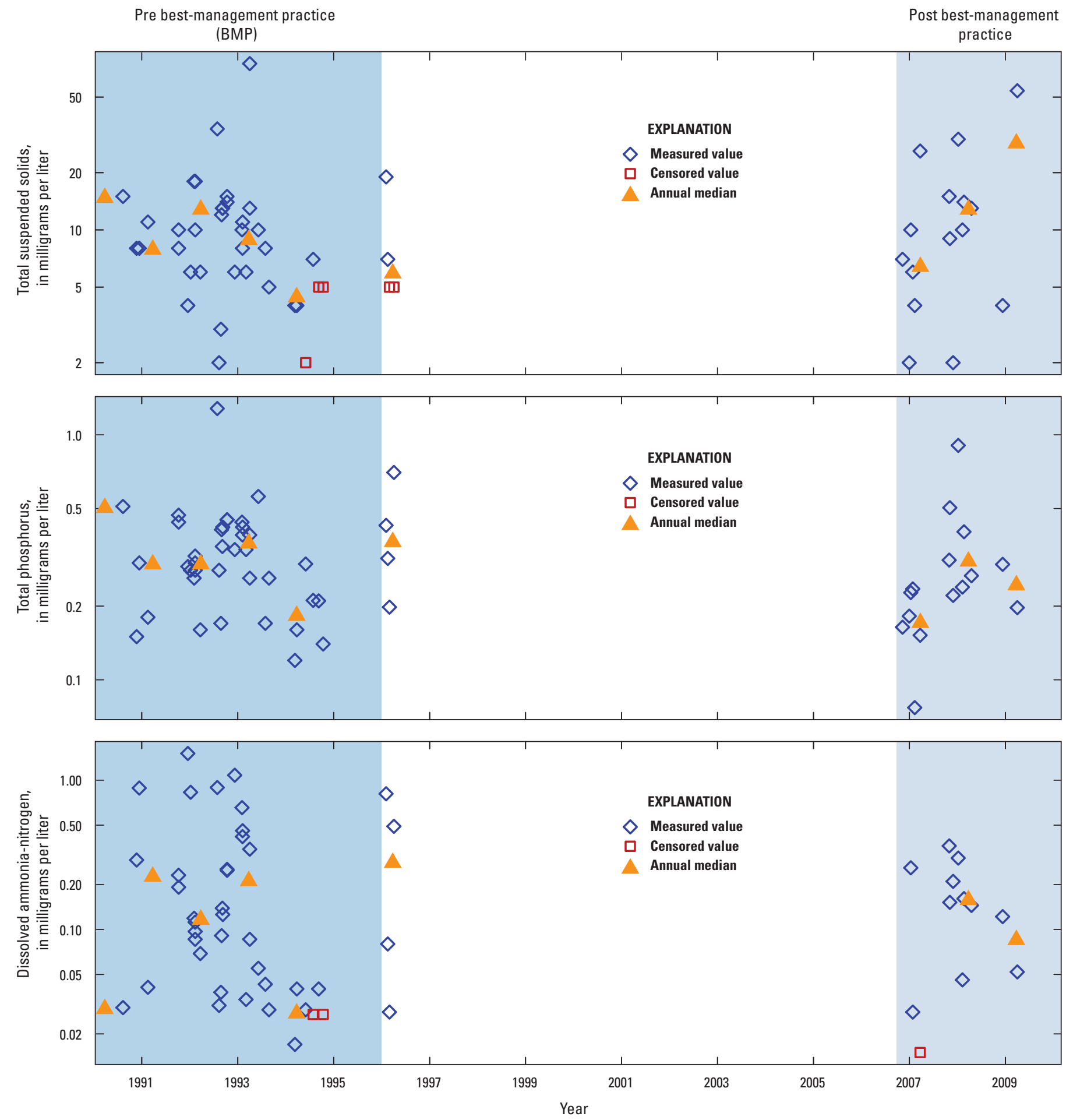

Figure 11. Concentrations and water-year medians of total suspended solids, total phosphorus, and dissolved ammonia nitrogen in base-flow samples throughout the study period at Bower Creek, Brown County, Wisconsin. 
Table 2. Results of Wilcoxon rank-sum test for differences between constituent concentrations in baseflow samples from pre- and post-best management practice implementation periods at Bower Creek, Brown County, Wisconsin.

[BMP, best-management practice; $\mathrm{mg} / \mathrm{L}$, milligrams per liter; bold text indicates a statistically significant change in concentration between pre- and post-BMP implementation periods]

\begin{tabular}{lcccc}
\hline & Number of & \multicolumn{2}{c}{ Median concentration (mg/L) } \\
\cline { 5 - 5 } \multicolumn{1}{c}{ Response variable } & $\begin{array}{c}\text { Numples for } \\
\text { sare-/post- }\end{array}$ & Pre-BMP & Post-BMP & $\begin{array}{c}\text { Significance } \\
\text { level }\end{array}$ \\
\hline BMP periods & & 10.0 & 10.0 & 0.691 \\
\hline Total suspended solids & $29 / 15$ & 0.340 & 0.235 & $\mathbf{0 . 0 2 6}$ \\
Total phosphorus as P & $29 / 15$ & 0.139 & 0.149 & 0.398 \\
Dissolved ammonia nitrogen as N & $29 / 12$ & & & \\
\hline
\end{tabular}

solution is to perform regressions relating the storm loads to variables representing climatic and seasonal conditions. If the explanatory variables remove variability representing the natural climatologic and seasonal conditions, then the variability remaining in the regression residuals represents the combination of changes induced by the BMPs and model error. Because the regression, by design, reduces the variability in the data, it should theoretically be possible to detect smaller differences between the pre- and post-BMP implementation periods than to detect differences by using the storm loads directly.

Several explanatory variables were selected for use in the regressions, most of which were based on various measures of rainfall or antecedent watershed conditions for each distinct rainstorm. These included total rainfall $(\mathrm{P})$, the 15- and 30-minute maximum intensities (I15 and I30), and the Universal Soil Loss Equation (USLE) erosivity index (EI) (Wischmeier and Smith, 1978). Additional rainfallbased measures included the 1-, 3-, and 5-day antecedent rainfall (API1, API3, and API5), which is computed as the total rainfall for the 1,3, and 5 days before the beginning of each storm, respectively. For this, terms combining total rainfall and the antecedent rainfall also were considered (for example, P+API1). Antecedent base flow (base flow on the day before the storm) was used as another measure of watershed condition preceding the storm. Finally, two seasonal terms were included to allow for variations arising solely on the basis of the time of year. The seasonal terms were based on the serial date of the storm (T), using a period of 1 year, and sine and cosine terms to allow for amplitude and phaseshift estimation.

Preliminary regression results indicated that, for many of the constituents and storms, simple linear regressions resulted in the prediction of negative storm loads. Because this would result in erroneous conclusions when comparing pre- and post-BMP implementation periods, the final regressions were based on a logarithmic transformation of the storm loads, thus assuring that negative loads cannot be predicted.

For each constituent, stepwise regressions were done on the explanatory variables described above (table 3 ). For each regression, additional variables were considered if the improvement in the resulting regression was considered large enough to warrant their use (a coefficient significantly different from zero at the 95-percent confidence level). In addition, various regression plots were examined to verify that the underlying assumptions of regression analysis were not violated.

Previous watersheds evaluated for BMP effectiveness through this program indicated that statistically significant differences of the median storm load could be detected at reduction levels of 28-89 percent (Graczyk and others, 2012; Corsi and others, 2005; and Graczyk and others, 2003). In addition, differences in median storm loads were observed between 18 and 73 percent that were not statistically significant. For Bower Creek, an evaluation of detectable change was determined to be between 37 and 76 percent based on evaluation of pre-BMP period data (Walker and others, 1995). The ability to detect changes that are significant relies

Table 3. Regression results for storm loads from rainfall periods from 1990-1997 and 2006-2009 at Bower Creek, Wisconsin.

$\left[\mathrm{R}^{2}\right.$, fraction of the variance of response variables explained by the explanatory variables for the model; Lbf, natural log of base flow on the previous day; API1, sum of rainfall for 24 hours preceding the event; API3, sum of rainfall for 3 days preceding the event; T, serial date of the storm; P, total precipitation; LEi, natural $\log$ of the Universal Soil Loss Equation erosivity index]

\begin{tabular}{llccc}
\hline \multicolumn{1}{c}{ Response variable } & \multicolumn{1}{c}{ Explanatory variables } & $\begin{array}{c}\text { Sample } \\
\text { size }\end{array}$ & $\begin{array}{c}\text { Adjusted } \\
\mathbf{R}^{2}\end{array}$ & $\begin{array}{c}\text { Standard error } \\
\text { (percent) }\end{array}$ \\
\hline Total suspended solids & Lbf, API1, API3, sin(T), P+API1, P+API3 & 34 & 0.63 & 1.36 \\
Total phosphorus as P & Lbf, API1, API3, P+API1, P+API3 & 34 & 0.63 & 1.02 \\
Dissolved ammonia nitrogen as N & Lbf, P+API1, LEi & 32 & 0.462 & 1.37 \\
\hline
\end{tabular}


on the magnitude of change as well as variability in the storm load residuals after regressions have been applied.

The regression residuals were tested for differences between the pre- and post-BMP implementation periods (table 4). The median storm loads from rainfall periods for all three constituents for the pre-BMP and post-BMP implementation periods are also listed in table 4. Regression residuals for the two periods were compared statistically by means of the Wilcoxon rank- sum test, as described previously in the section Water Quality Before and After Installation of Best-Management Practices. If the regressions represent the variability due to natural factors, a difference in the regression residuals could be attributed directly to a difference due to the BMPs.

For total suspended solids and total phosphorus, a decrease was observed in median storm loads from rainfall periods. For dissolved ammonia nitrogen, an increase was observed. Testing the storm-load residuals demonstrates that these changes were not statistically significant for any of the constituents at the 95-percent confidence level (table 4). Therefore, the differences in pre- and post-BMP conditions are likely not due to the BMPs installed, but more likely to be due to natural variability from variable hydrologic or seasonal conditions.

\section{Effects of Best-Management Practices on Bower Creek}

A substantial number of BMPs were implemented in the three primary categories targeted in the Bower Creek watershed (table 1). For the animal-waste category, about 70 percent of the targeted manure storage and barnyardrunoff control systems were implemented. Installation of the barnyard-runoff control systems provided the extra benefit of controlling most of the animal access to the stream channels, because the Bower Creek stream channel was previously accessed by livestock in or adjacent to the feedlots. All targeted stream bank fencing, shaping, and seeding listed under the stream bank protection category was completed during the project period. A new county ordinance requiring 20- to 35-foot riparian buffer strips resulted in over 16 acres of riparian buffer strips. Implementation of BMPs in the upland management category included preparation of nutrient management plans for most of the farms and almost 50 percent of the upland BMPs implemented. A description of individual BMPs and their potential effects on water quality has been previously published (Graczyk and others, 2003).

\section{Effects of BMPs on Water Quality}

Despite the implementation of many BMPs in the Bower Creek Watershed, the sampling results indicate no substantial improvement in most measures of water quality.

Base-flow concentrations were significantly reduced for total phosphorus, but not for total suspended solids and dissolved ammonia nitrogen. Storm loads observed after implementation of BMPs were not significantly different than those observed before implementation began. Significant improvements in water quality have been observed at other Whole Stream Monitoring projects (Graczyk, 2003; Corsi, 2005; Graczyk, 2012). At 4 of the 5 other streams included in the Whole Stream Monitoring projects, a significant reduction was observed in pollutant concentrations during base flow and storm loadings.

Understanding the effects of specific pollutant sources in a watershed is a complex task. Important factors include the land use, topography, condition of the land, proximity to the stream, likelihood of runoff from each area to reach the stream under different conditions, BMPs installed, effectiveness of the BMPs, human actions that affect drainage, and other factors. To keep a detailed inventory of all of these factors requires personnel resources that are often not available to watershed managers. Without a detailed inventory, a substantial amount of uncertainty exists in evaluation of source effects on water quality. Given this uncertainty and the expected benefits of each BMP to the overall quality of a stream, it is difficult to explain why this level of BMP implementation did not do more to improve the water quality in Bower Creek. For the purpose of improving BMP implementation efforts in the future, it is important to explore potential reasons that improvements in base-flow concentrations and storm loads were not observed for Bower Creek Watershed.

Base-flow Concentrations: Results from other monitoring projects in Wisconsin agricultural watersheds might help

Table 4. Median and mean rainfall-period storm loads and results of the Wilcoxon rank-sum test comparing storm-load residuals for pre- and post-best management practice implementation periods at Bower Creek, Wisconsin.

[BMP, best-management practice; lbs, pounds]

\begin{tabular}{lccccccc}
\hline \multirow{2}{*}{ Variable } & \multicolumn{2}{c}{ Median storm loads } & & \multicolumn{2}{c}{ Mean storm loads } & \multicolumn{2}{c}{ Storm-load residuals } \\
\cline { 2 - 3 } & Pre-BMP & Post-BMP & & Pre-BMP & Post-BMP & Significance level \\
\hline Total suspended solids (tons) & 18.98 & 9.51 & & 151 & 103 & \\
Total phosphorus as P (lbs) & 228 & 185 & & 790 & 533 & \\
Dissolved ammonia nitrogen as N (lbs) & 59 & 145 & & 261 & 163 & \\
\hline
\end{tabular}


explain the lack of response in the base-flow concentrations of ammonia nitrogen and total suspended solids. A reduction in total phosphorus base-flow concentrations indicate some benefit of the BMPs, such as limiting cattle access to the stream and nutrient management, but the post-BMP median base-flow concentration of 0.24 milligrams per liter $(\mathrm{mg} / \mathrm{L})$ is still much higher than the $0.075 \mathrm{mg} / \mathrm{L}$ targeted for streams of this size (Robertson and others, 2006). Results from the three other Whole Stream Monitoring projects indicated that median total phosphorus concentrations during pre-BMP base flow were from 0.07 to $0.09 \mathrm{mg} / \mathrm{L}$ compared to a much higher median of $0.34 \mathrm{mg} / \mathrm{L}$ at Bower Creek (Graczyk, 2003: Corsi, 2005; Graczyk, 2012). A large number of drain tiles have been installed in the Bower Creek Watershed (Jon Bechle, Brown County Land and Water Conservation Department, oral commun. 2012), which could be an important delivery system of total phosphorus to Bower Creek during non-event periods. Results from monitoring of drain tiles for the Discovery Farm program in Wisconsin indicated that drain tiles can flow all year long, and contribute substantial amounts of total phosphorus and ammonia nitrogen to the receiving streams (Discovery Farms, 2010). BMP implementation in the Bower Creek watershed did not focus on reduction of non-event flows from drain tiles (Jon Bechle, Brown County Land and Water Conservation Department, oral commun. 2012).

Total suspended solids concentrations measured during base-flow conditions for the three other Whole Stream Monitoring projects indicate a significant reduction in the total suspended solids concentration. This result was attributed to a large pre-BMP concentration followed by a large reduction in the number of cows with access to the stream (Graczyk, 2003: Corsi, 2005; Graczyk, 2012). A reduction in the base-flow concentration of total suspended solids in Bower Creek might be expected, because most of the cow access to the stream was reduced. This benefit might not have been observed, because of the low median pre-BMP total suspended solids concentration of $10 \mathrm{mg} / \mathrm{L}$ and the fact the drain tiles can contribute total suspended solids to the stream most of the year (Discovery Farms, 2010). In comparison, pre-BMP median base-flow concentrations for five other streams evaluated previously ranged from $9 \mathrm{mg} / \mathrm{L}$ to $62 \mathrm{mg} / \mathrm{L}$ (Graczyk and others, 2003; Corsi and others, 2005, Graczyk and others, 2012).

Storm Loads: Unlike base-flow concentrations, storm loads are more a consequence of sources activated by runoff events. These sources include upland areas, barnyards, and woodlots as well as eroding stream banks and drain tiles that were previously discussed as contributing to elevated baseflow concentrations. Woodlots are 6 percent of the watershed and not considered to be a critical source of contaminants, but storm loads generated by the rest of sources in the Bower Creek watershed are considered high. Results from monitoring small watersheds in the Southeastern Wisconsin Till Plains ecoregion indicated that Bower Creek had the second largest annual median total suspended solids (of 14 sites) and total phosphorus (of 12 sites) unit area loads at 131 tons $/ \mathrm{mi}^{2}$ and
685 pounds per square mile respectively (Corsi and others, 1997). In the present study, storm loads accounted for 92 percent of total suspended solids loads, 79 percent of total phosphorus loads, and 64 percent of ammonia nitrogen loads (fig. 9). Such high storm loads would seem to make it easier to observe some reduction as a result of BMPs, but emphasis on storm loads also means targeting the sources with the largest storm load potential is important. All of the above sources must be considered when evaluating the potential reasons the management practices did not significantly reduce the storm loads in the Bower Creek watershed.

Two potential reasons the storm loads were not reduced are (1) changes in productivity for the population of milk cows in the watershed and (2) the existing BMPs do not address all the sources. In the approximate time frame of the monitoring activities (1981 to 2008) there was only a small increase in the number of cows in Brown County, but the average milk production grew from 13,200 to 22,300 pounds per cow per year which is also thought to reflect changes in milk production from the pre-BMP to the post-BMP implementation periods (Bechle, oral commun. 2012). Because milk production increased so substantially, manure production also increased (U.S. Department of Agriculture, Natural Resources Conservation Service, 2009); therefore, field applications of manure increased through the study period. In the same time frame, the number of herds in Brown County declined from 1,348 to 239, indicating that manure was concentrated in fewer places. According to Brown County records, this information was also indicative of the situation in Bower Creek; therefore, with little change in the number of cows in Bower Creek, manure production increased, and became more concentrated at fewer farms in the watershed throughout the study period. Because of the manure distribution systems in place, these circumstances led to a greater amount of manure applied to the fields in the postBMP implementation period.

In addition, changes in cropping practices resulted in less erosion protection that resulted in less ground cover over the winter. The changes in cropping practices included (1) more land in soybeans, corn, and wheat; (2) less land in hay and other cover crops; (3) less conservation tillage; (4) oats eliminated as a crop; and (5) more land in corn silage (Bechle, oral commun. 2012). Between 1981 and 2008, the land used for growing soybeans in Brown County increased from 200 to 22,400 acres and the land used for growing hay declined from 74,000 to 61,000 acres. With these increases in manure production and changes in cropping practices, one may have expected storm loads to increase during the monitoring period, but no significant change in the storm loads over the study period was observed.

Collectively, all of this manure production and cropping information may indicate that the implemented BMPs, such as animal-waste management and upland management, did benefit the watershed by preventing an increase in pollutant loadings in Bower Creek. More data would be needed to support definitive conclusions on this topic. 
Given the water quality observed during this study, it seems that more BMPs are needed to achieve stormload reduction goals for the existing agricultural activities. Results from other Whole Stream Monitoring projects indicate sufficient BMPs can be implemented in a watershed to reduce the storm loads (Corsi, 2005; Graczyk, 2012). Previous management efforts achieved a high level of implementation of animal-waste management BMPs, but 50 percent of the targeted barnyard-runoff control measures were not implemented. In addition, there are still substantial targeted areas remaining for future implementation of upland management BMPs (table 1). Soil test phosphorus values (50 to more than $100 \mathrm{ppm}$ ) for a number of fields in Bower Creek Watershed pose an increased likelihood for phosphorus loading contributions to Bower Creek from upland erosion (Kelling and others, 2005). Brown County staff have recommended more grassed waterways and buffer strips be installed in an attempt to reduce sediment and phosphorus delivery (Bechle, oral commun. 2012). A large number of farms have nutrient management plans in place, but some have not been fully implemented because of remaining unaddressed concentrated flow areas, such as dead furrows (plowed trenches meant to help drain fields more efficiently) and fields without grassed waterways (fig. 12). The Brown County staff suggests that it may be beneficial to review how well these nutrient management plans are being implemented.

An upland pollutant transport system that likely needs more consideration and management is the robust network of drain tiles within the watershed. This drainage system enhances efficiency of runoff and allows farmers access to work in fields earlier than without the drain tiles, but it also provides an efficient pollutant transport system directly to the stream. Previous monitoring of agricultural drain tiles through Wisconsin's Discovery Farms program in Kewaunee County determined that $34 \%$ of the annual total phosphorus load and $25 \%$ of the sediment load from the monitored fields were delivered through the drain tiles (Discovery Farms, 2010). Ammonia loads were substantial during periods of frozen ground. Installation of runoff management for drain tiles is not a BMP category considered for the Bower Creek Watershed, but this information from Discovery Farms monitoring results indicates that substantial reductions may be possible in Bower Creek with management of drain tile runoff.

\section{Comparison of Results to Watershed Improvement Objectives}

In the Nonpoint Source Control Plan for the East River Priority Watershed Project (Wisconsin Department of Natural Resources, 1993), the specific objectives for the Bower Creek Watershed are the following:
1. Restore wetlands and maintain existing wetlands for preservation of wildlife and habitat,

2. Improve the aquatic habitat for the resident fish population,

3. Reduce phosphorus delivered to Bower Creek and its tributaries,

4. Reduce nutrients delivered to Bower Creek and its tributaries, and

5. Reduce sediment delivered to Bower Creek and its tributaries.

Preliminary pollutant-reduction goals to help achieve these objectives were set at a 50-percent reduction of sediment loads and a 70-percent reduction of phosphorus loads. Data resulting from this project indicate that the water quality generally did not improve. The level of BMP implementation was high for all types of targeted areas except upland management and barnyard-runoff control systems. Considering that an estimated 97 percent of the total suspended solids that reaches Bower Creek originates from eroding cropland (Wisconsin Department of Natural Resources, 1993), additional upland management could potentially reduce pollutant loads substantially more.

In comparison to specific objectives of the Nonpoint Source Control Plan, the success of the project in meeting each individual objective varied. Specific objectives are addressed as follows:

1. Because wetlands were not monitored during this project, there is no assessment of restoration of wetlands for the Bower Creek Watershed.

2. Habitat and biology populations were not monitored for this project because flows during some periods were non-existent.

3. Median total phosphorus during base-flow periods was reduced from $0.34 \mathrm{mg} / \mathrm{L}$ in the pre BMP period to $0.24 \mathrm{mg} / \mathrm{L}$ in the post-BMP period, but storm loadings did not change.

4. Dissolved ammonia-nitrogen loadings were not reduced during the study period.

5. Total suspended sediment loadings were not reduced during the study period. 


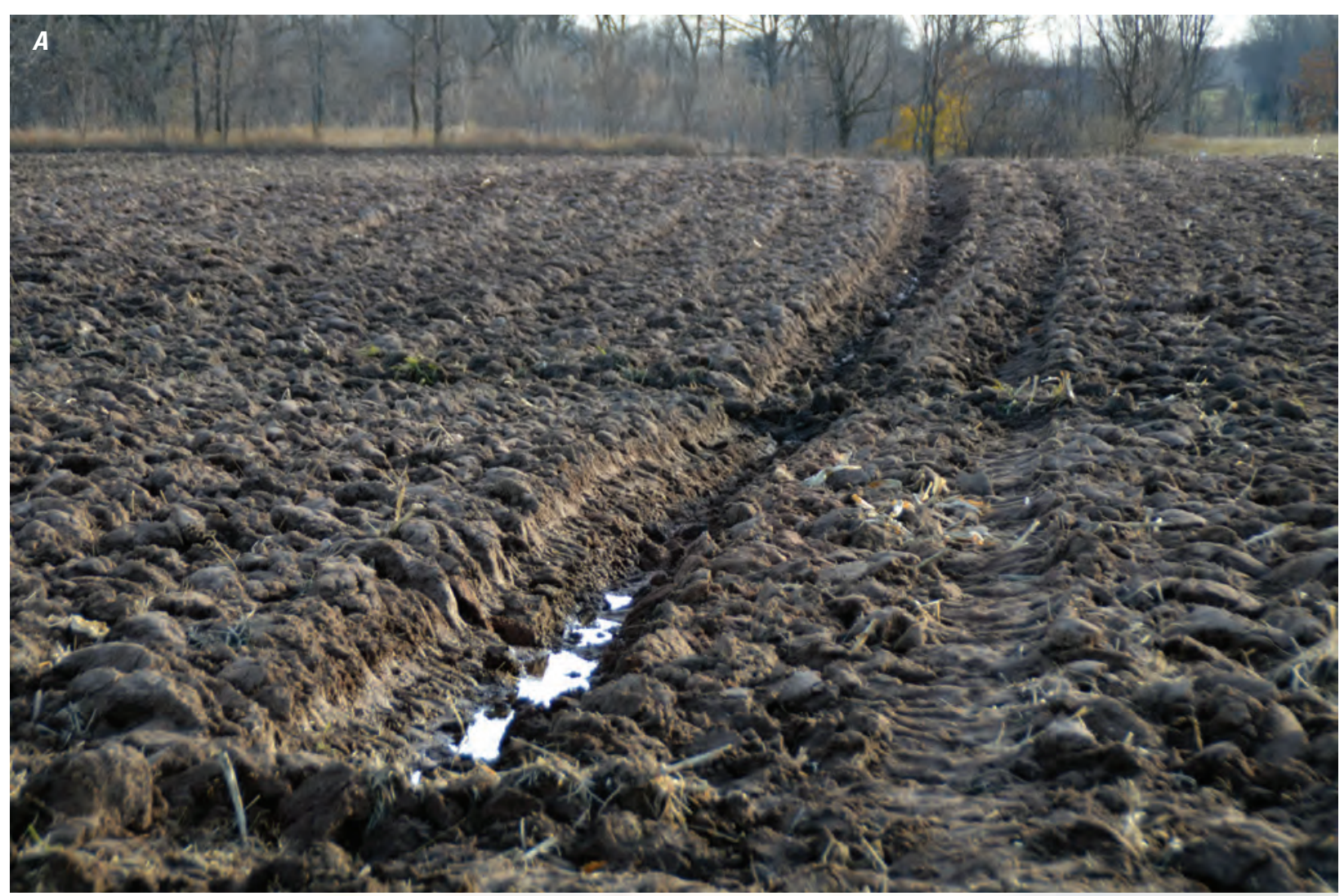

$B$

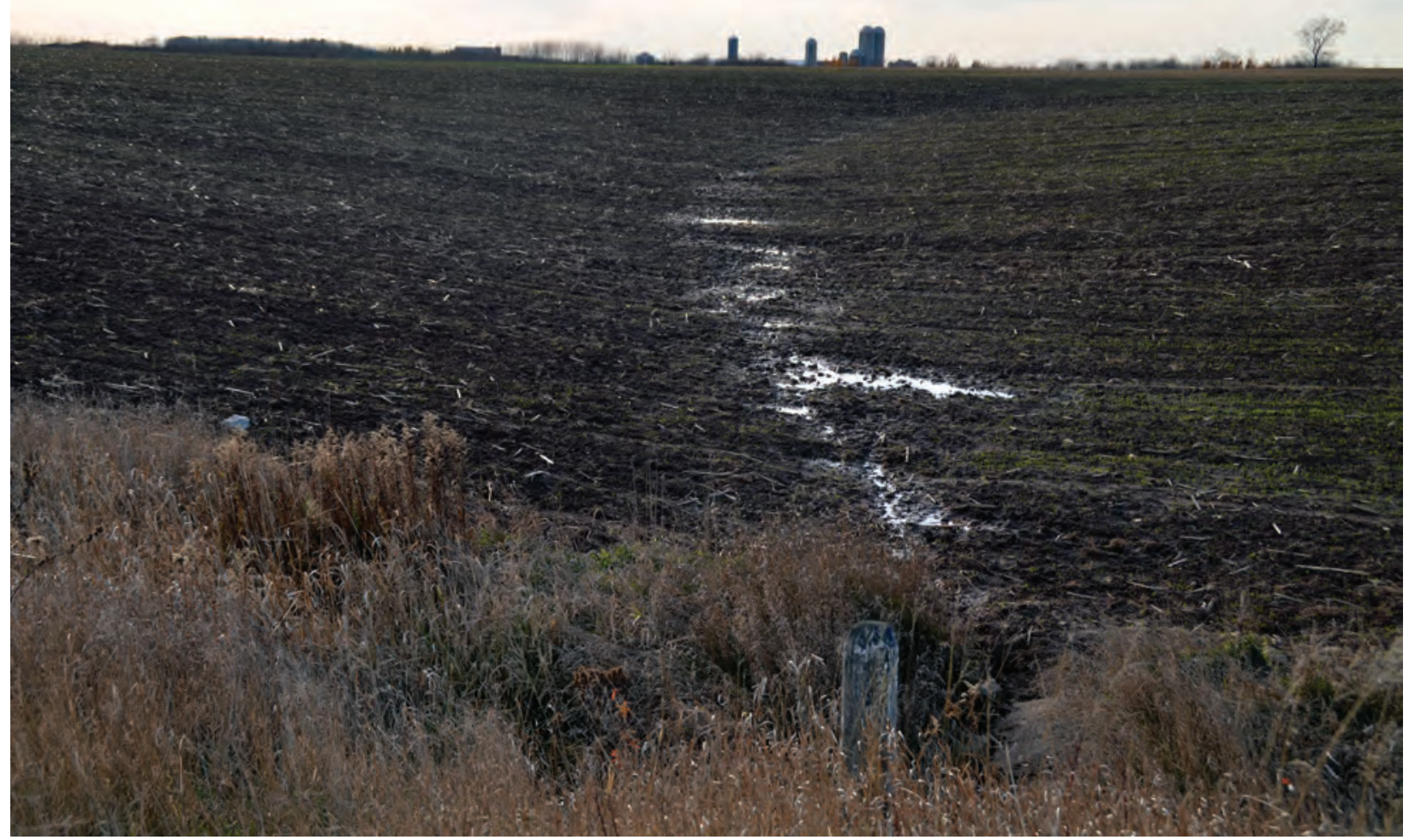

Figure 12. Examples of $A$, a dead furrow and $B$, an unaddressed concentrated flow area in the Bower Creek Watershed, Brown County, Wisconsin. 


\section{Summary and Conclusions}

The U.S. Geological Survey and the Wisconsin Department of Natural Resources began a comprehensive evaluation-monitoring program in 1989 to assess the effectiveness of best-management practices (BMPs), funded through the Wisconsin Nonpoint Source Program. Hydrologic and water-quality data were collected at Bower Creek from 1990 to 2009 with the pre-BMP period ending in July 1994 and the post-BMP period beginning in October 2006. BMPs installed in this watershed included streambank protection and fencing, stream crossings, grade stabilization, buffer strips, various barnyard-runoff controls, nutrient management, and a small amount of upland management.

Water-quality samples were collected during base flow and storms for the pre- and post-BMP implementation periods. Samples were analyzed for total suspended solids, total phosphorus, and dissolved ammonia nitrogen. Statistically significant differences between pre- and postBMP implementation periods were detected in median concentrations of total phosphorus, but not in total suspended solids and dissolved ammonia nitrogen in base-flow samples.

The median storm loads for total suspended solids, total phosphorus, and dissolved ammonia nitrogen during rainfall periods were compared statistically by means of the Wilcoxon rank-sum test. This test was also applied to regression residuals to test for differences between the pre- and postBMP implementation periods. Regression equations were constructed to remove some of the variability due to natural factors; a difference in the regression residuals is more likely to indicate a difference in water quality because of the BMPs than would a test of differences with the raw storm-load data. Differences between the pre- and post-BMP storm loads from rainfall periods were not observed for total suspended solids, total phosphorus, or dissolved ammonia nitrogen.

\section{References Cited}

American Public Health Association, 1989, Standard methods for the examination of water and wastewater (17th ed.): Washington, D.C., American Public Health Association, [variously paged].

American Public Health Association, 1992, Standard methods for the examination of water and wastewater (18th ed.): Washington, D.C., American Public Health Association, [variously paged].

Corsi, S.R., Graczyk, D.J., Owens, D.W., and Bannerman, R.T., 1997, Unit-area loads of suspended sediment, suspended solids, and total phosphorus from small watersheds in Wisconsin: U.S. Geological Survey Fact Sheet 195-97, 4 p.
Corsi, S.R., Walker, J.F., Wang, L., Horwatich, J.A., and Bannerman, R.T., 2005, Effects of best management practices in Otter Creek in the Sheboygan River Priority Watershed, Wisconsin, 1990-2002: U.S. Geological Survey Scientific Investigations Report 2005-5009, 26 p.

Danz, M.E., Corsi, S.R., Graczyk, D.J., and Bannerman, R.T., 2010, Characterization of suspended solids and total phosphorus loadings from small watersheds in Wisconsin: U.S. Geological Survey Scientific Investigations Report 2010-5039, 16 p.

Discovery Farms, 2010, Understanding Nutrient \& Sediment Loss at Pagel's Ponderosa Dairy: Madison, Wisconsin, University of Wisconsin-Madison 16 p. (Also available at http://www.uwdiscoveryfarms.org/CompletedProjects/ PagelsPonderosa.aspx)

Edwards, T.K., and Glysson, G.D., 1988, Field methods for measurement of fluvial sediment: U.S. Geological Survey Open-File Report 86-531, 118 p.

Graczyk, D.J., Walker, J.F., Horwatich, J.A., and Bannerman, R.T., 2003, Effects of best-management practices in the Black Earth Creek Priority Watershed, Wisconsin, 1984-1998: U.S. Geological Survey Water-Resources Investigations Report 03-4163, $24 \mathrm{p}$.

Graczyk, D.J., Walker, J.F., Bannerman, R.T., and Rutter, T.D., 2012, Effects of best-management practices in Eagle and Joos Valley Creeks in the Waumandee Creek Priority Watershed, Wisconsin, 1990-2007: U.S. Geological Survey Scientific Investigations Report 2011-5119, 25 p.

Helsel, D.R., and Hirsch, R.M., 1992, Statistical methods in water resources: New York, Elsevier Science Publishing Company Inc., 522 p.

Holmstrom, B.K., Kammerer, P.A., Jr., and Erickson, R.M., 1992, Water resources data Wisconsin, water year 1991: U.S. Geological Survey Water-Data Report WI-91-1, $607 \mathrm{p}$.

Holmstrom, B.K., Kammerer, P.A., Jr., and Ellefson, B.R., 1993, Water resources data Wisconsin, water year 1992: U.S. Geological Survey Water-Data Report WI-92-1, $545 \mathrm{p}$.

Holmstrom, B.K., Kammerer, P.A., Jr., and Ellefson, B.R., 1994, Water resources data Wisconsin, water year 1993: U.S. Geological Survey Water-Data Report WI-93-1, $707 \mathrm{p}$.

Holmstrom, B.K., Kammerer, P.A., Jr., and Ellefson, B.R., 1995, Water resources data Wisconsin, water year 1994: U.S. Geological Survey Water-Data Report WI-94-1, $645 \mathrm{p}$. 
Holmstrom, B.K., Olson, D.L., and Ellefson, B.R., 1996, Water resources data Wisconsin, water year 1995: U.S. Geological Survey Water-Data Report WI-95-1, 562 p.

Holmstrom, B.K., Olson, D.L., and Ellefson, B.R., 1997, Water resources data Wisconsin, water year 1996: U.S. Geological Survey Water-Data Report WI-96-1, 464 p.

Holmstrom, B.K., Olson, D.L., and Ellefson, B.R., 1998, Water resources data Wisconsin, water year 1997: U.S. Geological Survey Water-Data Report WI-97-1, 506 p.

Kelling, K., Bundy, L.G., Ebling, A., 2003, Management Options for Farms with High Soil Test Phosphorus Levels: Nutrient and Pest Management (NPM) Program, Madison, Wisconsin, University of Wisconsin-Madison, 8 p.

Link, E.G., and others, 1974, Soil survey of Brown County, Wisconsin: U.S. Department of Agriculture, Soil Conservation Service, [variously paged].

National Oceanic and Atmospheric Administration, 2010, National Climate Data Center, Climate Data Online, accessed October, 2010, at http://www.ncdc.noaa.gov/oa/ ncdc.html.

Porterfield, G., 1972, Computation of fluvial-sediment discharge: U.S. Geological Survey Techniques of WaterResources Investigations, book 3, chap. C2, 66 p.

Rantz, S.E., and others, 1982, Measurement and computation of streamflow-Volume 2, Computation of discharge: U.S. Geological Survey Water-Supply Paper 2175, p. 285-631.

Rappold, K.F., Wierl [Horwatich], J.A., and Amerson, F.U., 1997, Watershed characteristics and land management in the nonpoint source evaluation monitoring watersheds in Wisconsin: U.S. Geological Survey Open-File Report 97-119, 39 p.

Robertson, D.M., Graczyk, D.J., Garrison, P.J., Wang, L., LaLiberte, G., and Bannerman, R.T., 2006, Nutrient concentrations and their relations to the biotic integrity of wadeable streams in Wisconsin: U.S. Geological Survey Professional Paper 1722, 156 p.

U.S. Geological Survey, 2008-10, Water resources data for the United States, water year 2007 through 2009-Wisconsin data, accessed October, 2010, at http://wdr.water.usgs.gov/.
U.S. Department of Agriculture, Natural Resources Conservation Service, 2009, Agricultural Waste Management Field Handbook, Part 651 (also available at http://www.info.usda.gov/viewerFS.aspx?hid=21430.)

Viessman, W.H., Knapp, J.W., Lewis, G.L., and Harbaugh, T.E., 1977, Introduction to hydrology, (2d ed): New York, Harper \& Row Publishers Inc., 704 p.

Walker, J.F., 1993, Techniques for detecting effects of bestmanagement practices on stream-water chemistry: U.S. Geological Survey Open-File Report 93-130, 16 p.

Walker, J.F., Graczyk, D.J., Corsi, S.R., Owens, D.W., Wierl, J.A., 1995, Evaluation of nonpoint-source contamination, Wisconsin-Land-use and best-management-practices inventory, selected streamwater-quality data, urbanwatershed quality assurance and quality control, constituent loads in rural streams, and snowmelt runoff analysis, water year 1994: U.S. Geological Survey Open-File Report 95-320, 21 p.

White, K.E., and Sloto, R.A., 1990, Base-flow frequency characteristics of selected Pennsylvania streams: U.S. Geological Survey Water-Resources Investigations Report 90-4160, 67 p.

Wierl [Horwatich], J.A., Rappold, K.F., and Amerson, F.U., 1996, Summary of the land-use inventory for the nonpointsource evaluation monitoring watersheds in Wisconsin: U.S. Geological Survey Open-File Report 96-123, 23 p.

Wischmeier, W.H., and Smith, D.D., 1978, Predicting rainfall erosion losses - a guide to conservation planning: U.S. Department of Agriculture Handbook, no. 537, 58 p.

Wisconsin Department of Natural Resources, 1978, Wisconsin Administrative Code, Chapter NR 120, Nonpoint Source Pollution Abatement Program Register, November 1989, No. 407, 26 p.

Wisconsin Department of Natural Resources, 1993, Nonpoint source control plan for the East River Priority Watershed Project: Wisconsin Department of Natural Resources Publication WR-274-93, [variously paged].

Wisconsin State Laboratory of Hygiene, 1992, Manual of analytical methods and quality assurance: Madison, Wis., University of Wisconsin, $330 \mathrm{p}$. 
This page has been left blank intentionally. 
Publishing support provided by the U.S. Geological Survey Science Publishing Network, Columbus, Pembroke, and Rolla Publishing Service Centers.

For more information concerning the research in this report, please contact:

Center Director

U.S. Geological Survey

Wisconsin Water Science Center

8505 Research Way

Middleton, Wi 53562

http://wi.water.usgs.gov/ 


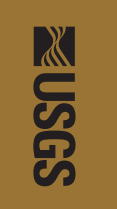

商.

咅

产

票

으

曲

$\stackrel{5}{1}$

ฏ

올

름

70

ํํํ.

三.

జ్ర

$\frac{7}{80}$

$\vec{\emptyset}$

ธั.

\&

를

홍

ह.

흘.

푱

옹

첩 